\title{
National Guidelines for the Treatment of Atopic Dermatitis
}

\author{
Svetlana POPADIĆ ${ }^{1}$, Mirjana GAJIĆ-VELJIĆ ${ }^{1}$, Sonja PRĆIĆ ${ }^{2}$, Željko MIJUŠKOVIĆ \\ Dragan JOVANOVIĆ 4 , Lidija KANDOLF-SEKULOVIĆ ${ }^{3}$, Miloš NIKOLIĆ ${ }^{1}$
}

${ }^{1}$ Clinic of Dermatovenereology, Clinical Center of Serbia, Department of Dermatovenereology, School of Medicine, University of Belgrade, Belgrade, Serbia

${ }^{2}$ Institute for Child and Youth Health Care of Vojvodina, Faculty of Medicine, University of Novi Sad, Serbia

${ }^{3}$ Clinic of Skin and Venereal Diseases, Military Medical Academy, Department of Dermatovenereology, School of Medicine, University of Belgrade, Belgrade, Serbia

${ }^{4}$ Department of Dermatovenereology, Clinic of Skin and Venereal Diseases, Clinical Center Nišs, School of Medicine, University of Niš, Nišs, Serbia

*Correspondence: Svetlana Popadić, E-mail:spopadic@med.bg.ac.rs

UDC 616.5-002-08(061.2)

DE GRUYTER
OPEN

\section{Epidemiology of atopic dermatitis}

Atopic dermatitis (AD) is a disease that usually presents in the early childhood (1). AD is one of the most common skin diseases and it affects approximately $20 \%$ of children and $1-3 \%$ of adults (2). In $60 \%$ of patients the first manifestations appear within the first year of life, and in $90 \%$ of patients before the age of five. In most patients manifestations of AD disappear before the adulthood, while in $25 \%$ of patients $\mathrm{AD}$ persists throughout life (2). Rarely, the first AD manifestations appear in adulthood (2). Approximately $25 \%$ of $\mathrm{AD}$ patients may develop some form of hand eczema during the life (3).

\section{Clinical presentations of $\mathrm{AD}$}

The clinical presentations of $\mathrm{AD}$ vary depending on the age and course of the disease; the major manifestations include erythema, edema, xerosis, erosions/excoriation, oozing and crusting, and lichenification $(1,4,5,6,7)$. Intense itching is common in $\mathrm{AD}$ resulting in excoriation, pruritic papules, lichenification and eczematous skin lesions $(2,3,4)$. The itch is particularly pronounced at night causing sleep impairment, thus having significant negative impact on the quality of life of both patients and their families $(2,3,5,6)$. The disease may take an acute, subacute or chronic course. Acute lesions are characterized by intense pruritus, presence of papules and vesicles on erythematous skin, and are associated with excoriation, erosion and serous exudates. Subacute lesions manifest as erythematous, excoriated scaly papules, while typical skin thickening with pronounced skin markings (lichenification) and pruritic papules are distinctive for the chronic course of the disease. In infants and young children, AD commonly starts as an acute or subacute condition, whereas chronic forms are characteristic for older children and adults $(5,6,7)$. These three distinct phases are often observed in the same patient $(6,7)$.

\section{Clinical presentations in children}

During the first month of life, the first signs of atopic dermatitis may present as pronounced yellowish scales on the scalp, commonly known as "cradle cap" or infantile seborrheic dermatitis (1). In infants, 3 - 6 months old, the predilection sites for eczematous changes on the face are cheeks, forehead and chin, whereas the central part of the face (nose, perioral region) and diaper area are often spared. Skin changes are acute or subacute, with unclear margins, and present with erythema, edema, papulovesicles, excoriations, often associated with oozing and crusting, while chronic changes are rare and manifest as erythematous papules and plaques with desquamation. In infants 8 - 10 months old, AD progresses to extensor surfaces of the extremities, and after the first year it may affect the upper trunk, where the changes manifest as nummular dermatitis $(1,5,6$, 7). After the age of 2 years, the clinical presentations change, that is, the disease takes a chronic course, or $\mathrm{AD}$ develops de novo. The symptoms include poorly marginated lichenified plaques with excoriations 
localized to cubital and popliteal fossae, on the neck and in the region of wrist and ankle joints. Dry skin affects the entire body. Lichenification occurs as a consequence of scraping and scratching due to intense (predominantly nocturnal) itching. At intervals, acute eczematous eruptions, manifesting as papules and papulovesicles, may develop on the lesions $(1,3,4,5)$. Adolescents often present with persistent lichenified plaques in large joint flexures, associated with chronic changes on the face (periorbital dermatitis), neck, hands, feet and back $(5,7)$.

\section{Clinical presentations in adults}

Adult patients with $\mathrm{AD}$ commonly present with lichenified plaques localized mainly in the flexural areas of the extremities and anogenital region. Facial edema associated with lichenification on the neck and eyelids, as well as chronic eczema on the hands and/or feet is a common finding. Pruritic type of $\mathrm{AD}$ is characterized by excoriated pruritic nodules. The disease may have a chronic recurrent course. Exacerbations often start with pronounced itching, without visible skin lesions, followed by erythema, papules and infiltrations $(1,5,6,7)$.

Patients with $\mathrm{AD}$ have increased susceptibility to skin infections, mostly those of bacterial etiology, but viral and fungalas well $(5,6,7,9)$. Bacterial infections are commonly associated with Staphylococcus aureus and somewhat more rarely with Streptococcus pyogenes $(6,7)$. Viral infections are more frequent in patients with $A D$, showing tendency of dissemination and spread of lesions $(1,8,10)$. Depending on the causative viral agent, eczema herpeticum, eczema molluscatum, eczema coxsackium or eczema vaccinatum may develop (1, 9, 10, 11). Fungal infections associated with Malassezia sympodialis (Pityrosporum ovale) lead to head and neck dermatitis (12).

The extent and severity of $\mathrm{AD}$ are estimated by SCORing atopic dermatitis (SCORAD) (usually used in Europe) and eczema area and severity index (EASI) (usually used in USA) indices (8).

\section{Etiopathogenesis of atopic dermatitis}

The etiopathogenesis of $\mathrm{AD}$ is multifactorial, including disturbances in skin barrier function, immune reaction with key role of T-cells, dendritic cells, lymphocytes, mast cells, eosinophils, as well as environmental factors. Skin barrier dysfunction in $\mathrm{AD}$ is a consequence to three main causes: reduced filaggrin gene expression, decreased level of ceramides in the skin, and increased activity of epidermal proteases. Almost $50 \%$ of patients with $\mathrm{AD}$ have a reduced expression for filaggrin gene synthesis, protein with a key role in maintaining the structural skin barrier function, while its absence, disturbing this structure, facilitates penetration of haptens and proteins $(13,14)$.

Ceramides are natural lipids essential for the retention of water in the corneal layer of epidermis. Patients with $\mathrm{AD}$ exhibit a significant decrease of ceramides, both in lesional and non-lesional skin. The amount of ceramides in the skin is in a reverse relation with transepidermal water loss, which is a characteristic of $\mathrm{AD}$ skin. The fact that in children, decreased amount of ceramides is sometimes found only in lesional skin, is explained as a postinflammatory reaction, not as a genetic factor $(13,14)$.

In regard to immunological aspects, the etiopathogenesis of $\mathrm{AD}$ is very complex, since it includes genes that encode factors of the adaptive and innate immune system. Skin resident cells, as keratinocytes, dendritic cells, mastocytes, macrophages and innate lymphocytes, have a role in the inflammatory reaction in patients with $\mathrm{AD}$. Besides, T-lymphocytes, plasmacytoid dendritic cells, monocytes and granulocytes from circulation also have a role in the etiology of eczematous reaction $(13,14)$.

In the pathogenesis of $\mathrm{AD}, \mathrm{T}$ helper (Th) lymphocytes have a central role. In $\mathrm{AD}$ patients, activity of specific ThLy clones is unbalanced, with predominance of Th2 cell response to allergens, which differs in healthy individuals, where Th1 response is dominant. Pathological activation of Th2 cells induces amplified production of IL4, IL5 and IL13, resulting in accumulation of other types of immune cells and development of acute lesions in $\mathrm{AD}$ patients. Contrary to acute AD lesions, Th1 cell activity is dominant in chronic AD lesions $(13,14)$.

Different incidence of $\mathrm{AD}$ in different geographical areas points to the significant role of environmental factors in its etiopathogenesis, such as climate factors, dietary factors, obesity, tobacco smoke exposure and microbiological exposure.

Novel studies highlighted the role and effects of skin microbiome both on its homeostasis as well as on the onset of different pathological conditions, including 
AD. In episodes of $\mathrm{AD}$ exacerbation, increased amount of $S$. aureus, but also $S$. epidermidis is evident. Exacerbation of cutaneous inflammation is mediated by superantigens such as staphylococcus enterotoxins $A$ and $B$, as well as toxic shock syndrome toxin 1 which result in $\mathrm{T}$ cells polyclonal activation $(13,14)$.
Increases in Streptococcus, Propionibacterium and Corynebacterium species on the skin are observed following therapy, also with differences to the skin microbiota of healthy individuals (13). Differences of gut and intestinal microbiota between $\mathrm{AD}$ patients and healthy individuals are also shown (13).

Table 1. Diagnostic criteria for atopic dermatitis by Hanifin and Rajka

\section{Major (3 of 4)}

- Pruritus

- Typical morphology and distribution of sk lesions: flexural dermatitis in children older than years and adults; facial dermatitis in infants

- Chronic or chronic relapsing course

- Personal and/or family history of atopy

\section{Minor (at least 3)}

- Positive prick allergy tests

- Increased total IgE concentration

- Early onset of disease

- Dry skin

- Facial pallor and/or redness

- Pityriasis alba

- Ichthyosis

- Orbital darkening

- Dennie-Morgan infraorbital folds

- Palmar hyperlinearity

- Keratosis pilaris

- Cheilitis

- Hand and foot eczema

- Areolar eczema

- Pruritus upon sweating

- Wool intolerance

- White dermographism

- Perifollicular accentuation

- Anterior neck folds

- Subcapsular cataract and keratoconus

- Susceptibility to bacterial and viral infections (S. aureus, HSV)

- Decreased cell-mediated immunity

- Worsening of skin condition under emotional, environmental stressors and irritants

- Food intolerance, especially in children younger than 2 years 
In regard to the climate factors, UV exposition and worm climate show protective effects on the onset of eczema, contrary to decreased UV exposition and high humidity.

Acidic $\mathrm{pH}$ of the skin, which contributes to the repair of the barrier function, has antibacterial effect and role in desquamation. In $\mathrm{AD}$ patients, $\mathrm{pH}$ of the entire skin is increased, resulting in exacerbation of the disease. The most common factors that disturb the $\mathrm{pH}$ of the skin are detergents and soaps. They change the amount of the lipids on the skin surface, enhance proteases and make the corneal layer thinner $(13,14)$.

The interaction of above-mentioned genetic factors, immune factors and environmental factors is very complex in the etiopathogenesis of $\mathrm{AD}$. With a great amount of new discoveries in this field, this is for sure a great challenge for further investigations in this area.

\section{Diagnostic criteria for atopic dermatitis}

The European Task Force on Atopic Dermatitis defined atopy as a genetic susceptibility to Th2 immune response to usual environmental allergens with clinical signs and symptoms of asthma, allergic and/or atopic dermatitis. In the majority of patients, the diagnosis of atopic dermatitis is based on personal history and typical clinical manifestations. Various diagnostic criteria have been developed in recent decades, but they are most important for epidemiological and clinical studies to define inclusion criteria $(1,15,16)$.

Diagnostic criteria for atopic dermatitis include combinations of clinical signs and symptoms, allergy tests and laboratory test results that confirm the presence of atopy. The most popular diagnostic criteria were developed by Hanifin and Rajka in 1980 (Table 1) (15). According to these criteria, 3 major and 3 minor criteria are needed for the diagnosis of atopic dermatitis. These criteria were validated in 2 studies, showing a diagnostic sensitivity of $87.9 \%$ and $96 \%$ and specificity of $77.6 \%$ and $93 \%$, respectively (16).

The second, less frequently employed criteria are those of UK Working Party's Criteria. Based on these criteria, atopic dermatitis is diagnosed in persons with typical skin lesions in the last 12 months, and at least 3 of 4 following criteria: early onset under the age of 2 (not used in children under the age of 4 ), personal history or current presence of flexural dermatitis, dry skin and personal history of atopy (or family history in children younger than 4 years) (17). These criteria were validated in numerous studies, with specificity of $10-100 \%$ and sensitivity of $89-99 \%$.

Furthermore, the American Academy of Dermatology recommended criteria which were divided into: essential, important, and associated features, based on their frequency and importance (18). Several other criteria were also recommended, but without wider acceptance in everyday clinical practice $(19,20)$.

In recent analysis and systematic literature review of all the studies that examined validity of different diagnostic criteria, the authors concluded that methodology of validation should be more uniform in order to draw the final conclusion of their utility (16)

\section{Emollient therapy and skin care in $\mathrm{AD}$}

The management of $\mathrm{AD}$ requires efficient control of flares by treatment of acute inflammatory symptoms, along with restoration of the skin barrier homeostasis, and avoidance of trigger and exacerbating factors. Certain moisturizers may improve the skin barrier function and reduce skin susceptibility to irritants $(21,22)$.

\section{Cleansing and bathing}

In general, dryness is worse during cold months, when it is aggravated by heat in the house and low humidity. Daily baths are considered an excellent means of hydrating the skin. The skin must be cleansed thoroughly, but gently and carefully. A daily bath or shower removes scales, crusts, irritants, and allergens and provides an opportunity to moisturize the skin. The water should be lukewarm, and $20 \mathrm{~min}$ immersion is adequate. Short baths (only 5 minutes) and the use of bath oils (in the last 2 minutes of bathing) are aimed at avoiding epidermal dehydration $(8,23)$. Soaps, shampoos, and shower gels and foams should be avoided; they can irritate and dry the skin. Prepubertal children produce little sebum and require minimal shampoo. Bath oils may have a moisturizing effect, but evidence for efficacy is limited. Neutral or low $\mathrm{pH}$ non-soap cleansers that are hypoallergenic and fragrance free are available, but any moisturizer cream or lotion can be used as a soap substitute. It is easiest to apply the moisturizer before getting into 
the bath or shower, and then massage it into the skin once in the water $(19,24)$. Topical emollients are preferentially applied immediately after taking a bath or a shower following gentle drying when the skin is still slightly humid. The key to maintaining hydration after bathing in patients with atopic dermatitis is application of a thick emollient within 3 minutes after exiting the bath, before evaporative loss occurs $(8,22$, 23).

\section{Emollient therapy}

Proper use of an emollient for hydration is a keystone of $\mathrm{AD}$ treatment and emollients are the mainstay of maintenance therapy. Emollients are available in various formulations. Lotions are thin with high water content and are useful for hairy areas and weeping eczema, but ineffective for severe xerosis. Gels are similar to lotions, with high water content. Creams (emulsions of water and oil) are most popular: easily rubbed in and do not leave a shine, but greasier than lotions and gels. Some oils solidify in cold climates, but soften at body temperature. Ointments are thick and greasy and are suitable for very dry eczema. However, they are less cosmetically acceptable, can cause heat trapping and folliculitis, and can stain clothing and bedding. Additives can cause irritation or allergy, and added fragrance should be avoided (24).

Patients should be encouraged to try different emollients, as well as advised about the best type for their skin condition, climatic conditions, and lifestyle. Hydration of the skin is usually maintained by application of moisturizers at least twice daily. Patients might use a gel- or cream-based emollient during the day and in hot weather, and an ointment at night and in cold weather. The amount needed is often underestimated. Approximately $600 \mathrm{~g} /$ week is required for adults and $250 \mathrm{~g} /$ week for children with generalized eczema. Emollients should be applied as liberally and frequently as possible (up to 4 hourly), ideally when the skin is moist from a bath. They should be used all over and not just to the affected skin and smoothed onto the skin in the direction of the hair follicles to avoid folliculitis $(19,24)$.

The use of emollients is widely recommended for the management of $\mathrm{AD}$, especially between flares. The direct use of emollients on inflamed skin is poorly tolerated and it is better to treat the acute flare first
(8). A regular use of emollient has a short and long term steroid sparing effect in mild to moderate AD. An induction of remission with topical corticosteroids is required first (short-term therapy). Maintenance of stable disease (long-term maintenance therapy) can be obtained with emollients used twice weekly or more frequently in a subset of patients, after an induction of remission with topical corticosteroids. The 1-week stand-alone application of an emollient, may offer benefits for the improvement of mild to moderately severe localized flares of $\mathrm{AD}$ (25).

An imbalance of skin microflora is suspected of playing a key role in exacerbations of AD. A twicedaily application of a new emollient balm, containing an extract of a non-pathogenic gram-negative bacteria, in children with mild $\mathrm{AD}$, protects the skin from $S$. aureus proliferation and preserves biodiversity of the microflora $(26,27)$.

\section{Topical anti-inflammatory therapy}

Effective topical therapy depends on three fundamental principles: sufficient strength, sufficient dosage and correct application. Topical treatment should always be applied on hydrated skin, especially when using ointments. Topical corticosteroids (TCS) and immunomodulators are first-line treatment of flares, whereas long-term management is based on the use of emollients that aim to improve skin hydration, maintain the barrier integrity, relieve pruritus and prevent new flares (28).. Patients with acute, oozing and erosive lesions, children in particular, sometimes do not tolerate standard topical application, and may first be treated with "wet wraps" until the oozing stops. They are highly effective in acute eczema and improve tolerance (29). Even without wet wraps, topical therapy is time consuming: patients should plan $30 \mathrm{~min}$ for one session. One well-conducted treatment per day is usually sufficient; oozing eczema may require a few days with higher treatment frequency (8).

By tradition, anti-inflammatory topical therapy has been administered to lesional skin only and has been stopped or tapered down once visible lesions were cleared. This traditional, reactive approach has in the last years been challenged by a proactive treatment concept, which is defined as a combination of predefined, long-term, low dose, anti-inflammatory treatment applied to previously affected areas of skin 
in combination with liberal use of emollients on the entire body and a predefined appointment schedule for clinical control examinations (30). The proactive, usually twice a week treatment regimen is initiated after all lesions have successfully been treated by an intensive, usually twice daily treatment approach in addition to ongoing emollient therapy for previously unaffected skin (8).

\section{Topical corticosteroids}

Topical corticosteroids (TCS) are important antiinflammatory drugs used in $\mathrm{AD}$, especially in the acute phase. TCS are recommended for AD-affected individuals who have failed to respond to good skin care and regular emollient use. Patient age, areas of the body affected, degree of xerosis, patient preference, and costs of medicines should be considered. TCS are a first-line anti-inflammatory treatment, applied on inflamed skin as needed (pruritus, sleeplessness, new flares) $(8,18,22)$. Twice-daily application of TCS is recommended, although once daily may be sufficient (25). There is no evidence for higher efficacy with application more than twice a day. Absorption is better with moisturized skin; after taking a bath is ideal, $20 \mathrm{~min}$ before applying the emollient. Itch is the key symptom for evaluation of response to treatment, and tapering should not be initiated before the itch has disappeared. Dose tapering should be gradual to avoid withdrawal rebound; tapering strategies consist of using a less potent corticosteroid on a daily base, or keeping a more potent one while reducing the frequency of application (intermittent regimen) (8). Proactive, intermittent use of TCS is recommended on areas that commonly flare $(18$, 22). Potential side effects should be considered. Monitoring for cutaneous side effects during longterm, potent TCS use is recommended. With mild activity, a small amount of topical corticosteroids twice to three times a week (monthly amounts in the mean range of $15 \mathrm{~g}$ in infants, $30 \mathrm{~g}$ in children, and up to $60-90 \mathrm{~g}$ in adolescents and adults), with a liberal use of emollients, generally allows a good maintenance keeping SCORAD values below 15 20. Such monthly amounts of even potent topical steroids usually do not have adverse systemic or local effects (8). The combination of topical corticosteroids with topical calcineurin inhibitors does not seem to be useful (31). The application amount of topical antiinflammatory therapy should follow the "finger-tip unit" (FTU) rule. A FTU is the amount of ointment expressed from a tube with a 5-mm diameter nozzle and measured from the distal interphalangeal joint to the tip of the index finger. One FTU is equivalent to approximately $0.5 \mathrm{~g}$ and should cover an area equal to both palms $(8,24)$.

\section{Topical calcineurin inhibitors}

Topical calcineurin inhibitors (TCI) are immunosuppressive agents which inhibit calcineurin in the skin, blocking early T-cell activation, and cytokine release. They are effective in reducing the skin inflammation in $\mathrm{AD}$ patients. In the $\mathrm{UK}$, tacrolimus $0.03 \%$ ointment and pimecrolimus $1 \%$ cream are approved for children aged $2-15$ years; tacrolimus $0.1 \%$ can be used $>16$ years $(28,32)$. Both topical calcineurin inhibitors are approved in the EU in patients above 2 years of age (8). In Serbia, pimecrolimus $1 \%$ cream is approved for children older than 2 years.

TCI are recommended for short-term, longterm, and maintenance treatment of $\mathrm{AD}$ in adults and children. TCI are preferable in situations that include recalcitrance to steroids, sensitive areas, steroidinduced atrophy, and long-term uninterrupted topical steroid use. They are particularly useful for areas where the skin is already thin, such as the face and flexures. TCI are recommended as steroid-sparing agents. For patients $<2$ years of age with mild-to-severe disease, off-label use of TCI can be recommended. Proactive intermittent use with TCI is recommended on areas that commonly flare $(18,22)$. Proactive tacrolimus ointment therapy, used twice a week, has shown to be safe and effective for up to 1 year in reducing the number of flares and improving the quality of life in adult patients and children (33).

Side effects, including skin burning and pruritus, should be considered and patients should be informed. The most common side-effect is a transient feeling of warmth or burning at the application site during the first days $(34,35)$. It starts about 5 min after each application and may last up to $1 \mathrm{~h}$, but intensity and duration typically decrease within 1 week to zero (36).

Clinicians should be aware of the black-box warning on the use of TCI $(18,22)$. Although effective sun protection is recommended in patients treated 
with TCI, there is no significant systemic absorption and TCI have been used in children for more than 15 years with no evidence of increased malignancy (24).

\section{Topical antipruritic therapy}

There is little specific and effective antipruritic treatment for eczema itch (37). There is evidence that TCS can be used in the initial phase of AD exacerbation to control pruritus. Also, TCI significantly relieve pruritus in $\mathrm{AD}$. Itch is completely relieved after the first days of treatment in adults and children.

\section{Specific antipruritic therapies}

Topical anesthetics (benzocaine, lidocaine, polidocanol, mixture of prilocaine and lidocaine) when used as short-term therapy may reduce itch in $\mathrm{AD}$ (8). Cannabinoid receptor agonists (N-palmitoylethanolamine, applied twice a day) have been described to exhibit antipruritic and analgesic properties (38). Capsaicin is a naturally occurring alkaloid which exerts its functions via binding to a capsaicin-specific receptor which is located on free nerve endings. There is preliminary evidence that capsaicin is useful in the treatment of AD itch (39). Topical doxepin (5\% cream) exhibited antipruritic effects in controlled studies of $\mathrm{AD}$ (40). However, topical doxepin therapy is not licensed or used in any European country due to an increased risk of contact allergy. Topical mast cell stabilizer sodium cromoglycate showed improvement in SCORAD (41). Other new topical agents include thiol derivative $\mathrm{N}$-acetylcysteine, but without convincing evidence of its efficacy in AD (42). At the moment, there is not enough evidence by randomised controlled trials (RCT) to support the use of these substances in the treatment of AD itch. However, none of these substances is licensed for $\mathrm{AD}$ in Europe, and routine clinical use is not recommended as an adjuvant antipruritic therapy in $\mathrm{AD}(8)$.

\section{Other anti-inflammatory agents}

The development of a more specific anti-inflammatory treatment which is easy to use and targets pruritus could provide clinically meaningful improvements for patients with $\mathrm{AD}$. The majority of emerging therapies for $\mathrm{AD}$ are focused on inhibiting phosphodiesterase 4 (PDE4), an enzyme which is increased in inflammatory disorders such as AD (43).
Topical crisaborole $2 \%$ ointment, (formerly known as AN2728) is a benzoxaborole, nonsteroidal, topical, anti-inflammatory phosphodiesterase4(PDE4) inhibitor. By inhibiting PDE4 and thus increasing levels of cyclic adenosine monophosphate (cAMP), crisaborole controls inflammation. Once crisaborole reaches systemic circulation after topical application, it is metabolized to inactive metabolites. This limits systemic exposure to crisaborole and systemic PDE4 inhibition. Crisaborole 2\% ointment was generally well tolerated and improved AD disease severity scores, pruritus, and all other $\mathrm{AD}$ signs and symptoms. Two large, randomized, controlled, phase 3 , clinical trials assessing the efficacy and safety of topical crisaborole $2 \%$ ointment, in children, adolescents, and adults with mild to moderate $\mathrm{AD}$, were recently completed with positive results $(44,45,46,47)$.

Tofacitinib is a small-molecule Janus kinase (JAK) inhibitor that affects the interleukin (IL) -4, IL-5, and IL-31 signaling pathways, interfering with the immune response that leads to inflammation. Tofacitinib 2\% ointment, applied twice daily for 4 weeks, showed significant efficacy and safety/local tolerability with early onset of AD. JAK inhibition through topical delivery is potentially a promising therapeutic target for AD (48).

\section{Systemic treatment of $\mathrm{AD}$}

The use of systemic corticosteroid therapy is not recommended in $\mathrm{AD}$ because of short-term, transient positive, and potential side effects.

During flares, oral H1-antihistamines, cephalosporins and macrolides are indicated. In severe, generalized and resistant forms of $\mathrm{AD}$, oral cyclosporine and methotrexate may be used. Methotrexate is not allowed before the age of two.

Antihistamines. Oral antihistamines (H1) are safe for long-term treatment. Although there are opinions that non-sedating antihistamines do not relieve pruritus in $\mathrm{AD}$ patients as sedating antihistamines, modern treatment protocols and our experience indicate that systemic therapy with non-sedating antihistamines reduces pruritus, has a positive impact on clinical presentations, and the quality of life in $\mathrm{AD}$ patients.

$\mathrm{H} 1$ antihistamines act via $\mathrm{H} 1$ receptor by inhibiting the response of mediators released by mast 
cells and basophils. Suppression of the inflammatory response is achieved by reducing chemotaxis and antigen presentation, reduced expression of cell adhesion molecules and reducing the levels of proinflammatory cytokines (49). Oral antihistamines alleviate pruritus in AD. Antihistamines are used once or several times a day, as recommended by the manufacturer.

Chloropyramine is an antihistamine that reduces pruritus and exhibits local anesthetic, local vasoconstrictor effect and central sedative effect. It is contraindicated during pregnancy and lactation, in newborns and premature infants. In children, it is recommended only in case of severe allergic reactions. We do not recommend it in the treatment of $\mathrm{AD}$ in pediatric patients. In adult patients caution is advised if there is an increased sensitivity to the sedative effects of antihistamines and comorbidities such as epilepsy, hyperthyroidism and others. It is used $1-3$ times during 24 hours by deep intramuscular or slow intravenous injection.

The newer, oral non-sedating antihistamines (loratadine, desloratadine, cetirizine, levocetirizine, etc.) are more comfortable and safe for long-term use. According to the manufacturer, they are used in a single dose (1x1 tablet/day). However, in dermatology we use it in up to four times higher doses. Desloratadine is an oral solution that can be used from the sixth month of life, while levocetirizine is recommended after the age of two. In addition to effects on $\mathrm{H} 1$ receptors, oral antihistamines also have anti-inflammatory effects improving the signs and symptoms of AD.

Antibiotics. Antibiotics (cephalosporins, and macrolides) are crucial during flares. An impaired epidermal barrier function enhances the development of infection. Furthermore, pruritus leads to scratching and dissemination of Staphylococcus aureus on inflamed and non-inflamed skin areas. Superantigen stimulation by $S$. aureus contributes to the development and maintenance of inflammation in $\mathrm{AD}(50,51)$. During flares, cephalexin is considered to be the drug of choice, while azithromycin may be used in patients allergic to penicillins and cephalosporins.

Antifungals. Fungal infections can also be associated with the development and maintenance of inflammation in AD. Head and neck variant of AD is often associated with increased Malassezia sympodialis
(52). Oral ketoconazole or itraconazole and topical ciclopiroxilamine or imidazole (miconazole, clotrimazole), during 7 - 14 days, reduce inflammation in patients with head and neck variant of the disease (53). Another imidazole preparation, fluconazole is also successfully used in this variant of AD.

Viral infections, particularly Molluscum contagiosum virus and herpes simplex, easily spread due disrupted skin barrier function in AD. Eczema herpeticum occurs almost exclusively in $\mathrm{AD}$ patients and may be a life-threatening infection, particularly in pediatric patients. The treatment of choice for Molluscum contagiosum is liquid nitrogen and curettage. Acyclovir is a drug of choice for eczema herpeticum (10).

Phototherapy. During summer and sunny months, $\mathrm{AD}$ tends to improve in most patients. Artificial, UVA and UVB phototherapy, have an important role in the treatment of $\mathrm{AD}$ in our country, especially during the late fall and winter. It was found that UV rays have a beneficial effect on the sensory innervations of the skin (54), induce apoptosis of inflammatory cells and reduce production of cytokines (55). UV radiation also recovers the skin/epidermal barrier function (56).

Currently, there are several available UV protocols:

Broadband UV (UVA + UVB $=290-400 \mathrm{~nm})$

Broadband Ultraviolet B (UVB-HB = $280-315 \mathrm{~nm}$ )

Narrow-band UVB (nbUVB = top: $311-313 \mathrm{~nm}$ )

UVA1 (340 - $400 \mathrm{~nm})$

Phototherapy is good as a maintenance therapy and as a support treatment. It is rarely used as a monotherapy in stages of disease exacerbation. PUVA therapy is not recommended in patients under the age of 12. In general, depending on the physical characteristics of UV chamber and patients' age, the initiation of UVB phototherapy in younger patients is individually estimated. Rarely the use of this type of therapy is possible before the age of five. During sunny months, controlled sun exposure is recommended.

Cyclosporine. Cyclosporine inhibits production of IL-2. The results of meta-analyses (57) confirm the efficacy of cyclosporine in the treatment of $\mathrm{AD}$. Rapid recurrence is possible after discontinuation of cyclosporine treatment. Before cyclosporine is initiated, control of blood pressure, serum creatinine, 
and basic biochemical analysis of blood and urine should be performed. The initial dose of cyclosporine is $2.5-5 \mathrm{mg} / \mathrm{kg}$ in two divided daily doses (every 12 h). At the beginning, lower doses of cyclosporine are recommended. Later, if the renal function, the serum concentration of cyclosporine and blood pressure are normal, the dose may be increased up to $5 \mathrm{mg} / \mathrm{kg} /$ day. Doses higher than $5 \mathrm{mg} / \mathrm{kg} /$ day may be associated with nephrotoxic effects.

Methotrexate. Methotrexate (MTX) is also successfully used in the treatment of severe forms of $\mathrm{AD}$. It is not recommended before the age of two. Before the introduction of MTX, complete blood count test (CBC), serum creatinine, AST, ALT as well as urine analysis, $\mathrm{HBsAg}$ and anti-HCV tests should be performed. The MTX test-dose is administered $5-7$ days before the first therapeutic dose. In pediatric patients (under the age of 5) $1.25 \mathrm{mg}$ (1/2 tablets) of MTX may be considered as a test dose, while in older and adult patients the test dose is $2.5 \mathrm{mg}$ ( $1 \mathrm{x} 1$ tablet). After $5-7$ days, CBC, hepatic function and urine analysis should be performed and if they are within normal limits therapeutic doses of MTX may be introduced. The initial therapeutic dosage for pediatric patients is $0.2-0.4 \mathrm{mg} / \mathrm{kg}$ weekly and 0.2 $\mathrm{mg} / \mathrm{kg}$ weekly in adult patients. MTX is administered in a single dose orally or subcutaneously. Laboratory tests (CBC, creatinine, hepatic function and urine) are performed once a week during the first month, then every two weeks in the second month, then monthly during treatment. After withdrawal of skin lesions or during remission we recommend slow tapering of MTX. In remission phase we recommend low doses of MTX (5-10 mg) for several months. In adult patients, contraception is necessary during the treatment and for six months after discontinuation of MTX. Folic acid, 5 mg a week should be administered 48 hours after MTX.

Azathioprine. Azathioprine is used in the UK and USA in the treatment of adult forms of $\mathrm{AD}$. Therapeutic dose is $2.5 \mathrm{mg} / \mathrm{kg} / \mathrm{day}$, in patients over 17 years of age (58). Before the introduction of azathioprine and during the treatment, $\mathrm{CBC}$, blood and urine tests are recommended. Contraception is necessary during the treatment with azathioprine.

Biologics. Numerous biologics (ustekinumab, fezakinumab, apremilast, dupilumab, OC000459) are used in the treatment of $\mathrm{AD}$, with promising results. However, so far, these preparations are not routinely used in the treatment of $\operatorname{AD}(59,60)$. Larger studies and longer follow-up periods will point to efficacy and safety of biologics in the treatment of $\mathrm{AD}$.

\section{General measures in $\mathrm{AD}$ patients Hygiene}

The skin should be cleaned thoroughly, but gently and carefully, in order to remove crusts in case of bacterial superinfection. Bathing should last approximately 5 10 minutes, water temperature between 27 and $30^{\circ} \mathrm{C}$. In order to avoid dehydration of the epidermis, patients are recommended to use a bath oil, during the final 2 minutes of bathing. Adding sodium hypochlorite to the bath water may be useful, considering its antibacterial effect (8). Taking a bath in salt water can be beneficial for patients with impetiginized lesions or ichthyosis. It has been shown that water hardness is linked with an increased AD prevalence, which means that hard water can increase the risk of atopic dermatitis in children (61).

Emollients are primarily applied immediately after a shower or bath, while the skin is still slightly damp. Newer studies have suggested that by limiting the amount of products used to clean the skin and by applying emollients at least once a day, the risk of atopic dermatitis can be reduced (62).

\section{Clothing}

Wearing smooth, cotton clothes and avoiding irritating fabrics (primarily wool) is crucial for avoiding skin irritation. In addition, overly occlusive clothing which increases the temperature of the skin should be avoided; in winter months, children should not be dressed too warmly. Low humidity and indoor heating make the skin drier, so the use of air humidifiers is recommended. There is a consensus that patients with atopic dermatitis should avoid occupations which involve a risk of serious skin damage or contact with irritating substances (8).

\section{Lifestyle}

Numerous factors and substances in our surroundings can irritate the sensitive skin of patients with $\mathrm{AD}$ and cause the development of eczema. The irritants may be mechanical (for example, wool), chemical (acids, solvents, water) or biological (microorganisms). Informing patients and their family members about 
the importance of non-specific irritants and their role in the development of eczema is an extremely important precondition for successful treatment of patients with $\mathrm{AD}$.

Many patients are aware of the fact that contact with animals can make their skin symptoms worse. The exposure to cat fur in childhood can increase the risk of $\mathrm{AD}$, especially in children with a filaggrin gene mutations $(8,63)$. There is no evidence that contacts with dogs increase the risk of $\mathrm{AD}(8)$.

Cigarette smoking in facilities or rooms where children with $\mathrm{AD}$ spend time should be avoided, since it can make the irritation and itching worse and increase the tendency towards the development of asthma later in life.

Many patients have problems with perspiration and sweat retention during the summer, which can intensify the itching. However, children with $\mathrm{AD}$ should be encouraged to actively play sports. Swimming is an excellent activity for children with $\mathrm{AD}$, if they can tolerate exposure to chlorinated water.

Spending time in air-conditioned rooms during the summer months can significantly decrease the itching.

\section{Diet}

Among the food allergens, cow's milk, eggs, wheat, soy, walnuts, and peanuts are usually responsible for the development or exacerbation of eczema in early childhood. Double-blind, placebo-controlled food challenges are considered to be the gold standard for food allergy diagnosis (64). In a systematic review of eight randomized, controlled trials (57) which examined the effect of elimination diets in patients with $\mathrm{AD}$, no conclusive evidence has been found to support the claim that an elimination diet (for example, eggs and milk) is beneficial for $\mathrm{AD}$ patients. However, another study has shown that egg-free diet has led to the improvement of $\mathrm{AD}$ in patients who have shown clinical symptoms since the last egg consumption (65).

Restrictive diets are not recommended for patients with $\mathrm{AD}$ who have not been diagnosed with a food allergy (66). Patients suffering from a mild or severe $\mathrm{AD}$ should follow elimination diets which exclude foods that cause a sore or delayed skin reaction which appears after the controlled oral provocation test has been conducted (8).
There is sound evidence that probiotics are safe and efficient in the prevention of $\mathrm{AD}$ and that they decrease the risk by about $20 \%$ (67). However, it is still unclear how probiotics should be taken (should mothers take them during pregnancy, should they be given to children when they are born, or both) and which strain should be taken. In contrast to their positive effect with regard to prevention, the efficacy of probiotics in patients suffering from $\mathrm{AD}$ has not been established (68).

\section{Alternative treatments}

There is insufficient evidence to determine whether phytotherapy, aromatherapy, acupuncture, homeopathy, traditional Chinese medicine, or bioresonance therapy are effective forms of treatment for $\mathrm{AD}(8)$.

\section{Abbreviations}

AD - Atopic dermatitis
EASI - Eczema area and severity index
FTU - "finger-tip unit"
JAK - Janus kinase
MTX- Methotrexate
nbUVB - Narrow-band UVB
PDE4 - phosphodiesterase 4
SCORAD - Scoring atopic dermatitis
Th - T helper
TCS - Topical corticosteroids
TCI - Topical calcineurin inhibitors
UVA - Ultraviolet A rays
UVB - Ultraviolet B rays

\section{Disclosure}

This study was partially supported by the Fund of The Serbian Ministry of Education and Science (Grants No 175065, 175038, 41018 and 43012).

\section{References:}

1. Wollenberg A, Oranje A, Deleuran M, Simon D, Szalai Z, Kunz B, et al. ETFAD/EADV Eczema task force 2015 position paper on diagnosis and treatment of atopic dermatitis in adult and paediatric patients. J Eur Acad Dermatol Venereol. 2016;30(5):729-47.

2. Williams HC. Clinical practice. Atopic dermatitis. N Engl J Med. 2005;352(22):2314-24.

3. Bingefors K, Svensson Å, Isacson D, Lindberg M. Self-reported lifetime prevalence of atopic dermatitis and co-morbidity with 
asthma and eczema in adulthood: a population-based crosssectional survey. Acta Derm Venereol. 2013;93(4):438-41.

4. Eichenfield LF, Tom WL, Chamlin SL, Feldman SR, Hanifin JM, Simpson EL, et al. Guidelines of care for the management of atopic dermatitis. Section 1. Diagnosis and assessment of atopic dermatitis. J Am Acad Dermatol. 2011;70(2):338-51.

5. Schneider L, Tilles S, Lio P, Boguniewicz M, Beck L, LeBovidge J, et al. Atopic dermatitis: a practice parameter update 2012. J Allergy Clin Immunol. 2013;131(2):295-9.

6. Leung DYM, Eichenfield LF, Boguniewicz M. Atopic Dermatitis (atopic eczema). In: Goldsmith A, Katz S, Gilchrist B, Paller A, Leffell D, Wolff K, editors. Fitzpatrick's dermatology in general medicine. 8th ed. New York: McGraw Hill Medical; 2012. p. 165-82.

7. Lipozenčić J, Ljubojević S, Gregurić S. Atopijski dermatitis u djece i odraslih [Atopic dermatitis in children and adults]. Acta Med Croatica. 2011;65(2):87-96.

8. Ring J, Alomar A, Bieber T, Deleuran M, Fink-Wagner A, Gelmetti C, et al. Guidelines for treatment of atopic eczema (atopic dermatitis) part I. J Eur Acad Dermatol Venereol. 2012;26(8):1045-60.

9. Galli E, Neri I, Ricci G, Baldo E, Barone M, Belloni Fortina A, et al. Consensus Conference on Clinical Management of Pediatric Atopic Dermatitis. Ital J Pediatr. 2016;42:1-25.

10. Wollenberg A, Wetzel S, Burgdorf WH, Haas J. Viral infections in atopic dermatitis: pathogenic aspects and clinical management. J Allergy Clin Immunol. 2003;112(4):667-74.

11. Wollenberg A, Zoch C, Wetzel S, Plewig G, Przybilla B. Predisposing factors and clinical features of eczema herpeticum: a retrospective analysis of 100 cases. J Am Acad Dermatol. 2003;49(2):198-205.

12.Darabi K, Hostetler SG, Bechtel MA, Zirwas M. The role of Malassezia in atopic dermatitis affecting the head and neck of adults. J Am Acad Dermatol. 2009;60(1):125-36.

13.McPherson T. Current understanding in pathogenesis of atopic dermatitis. Indian J Dermatol. 2016;61(6):649-55.

14.Peng W, Novak N. Pathogenesis of atopic dermatitis. Clin Exp Allergy. 2015;45(3):566-74.

15.Hanifin JM, Rajka G. Diagnostic features of atopic dermatitis. Acta Derm Venereol. 1980;92(Suppl):44-7.

16.Brenninkmeijer EE, Schram ME, Leeflang MM, Bos JD, Spuls PI. Diagnostic criteria for atopic dermatitis: a systematic review. Br J Dermatol. 2008;158(4):754-65.

17. Williams HC, Burney PG, Pembroke AC, Hay RJ. The U.K. working party's diagnostic criteria for atopic dermatitis. III. Independent hospital validation. $\mathrm{Br} \mathrm{J}$ Dermatol. 1994;131(3):406-16.

18.Eichenfield LF, Tom WL, Chamlin SL, Feldman SR, Hanifin JM, Simpson EL, et al. Guidelines of care for the management of atopic dermatitis: section 1. Diagnosis and assessment of atopic dermatitis. J Am Acad Dermatol. 2014;70(2):338-51.

19.Bos JD, Van Leent EJ, Sillevis Smitt JH. The millennium criteria for the diagnosis of atopic dermatitis. Exp Dermatol. 1998;7(4):132-8.

20.Diepgen TL, Sauerbrei W, Fartasch M. Development and validation of diagnostic scores for atopic dermatitis incorporating criteria of data quality and practical usefulness. J Clin Epidemiol. 1996;49(9):1031-8.

21.Bieber T, Akdis C, Lauener R, Traidl-Hoffmann C, Schmid-
Grendelmeier P, Schäppi G, et al. Global Allergy Forum and 3rd Davos Declaration 2015: Atopic dermatitis/eczema: challenges and opportunities toward precision medicine. Allergy. 2016;71(5):588-92.

22.Silverberg JI, Nelson DB, Yosipovitch G. Addressing treatment challenges in atopic dermatitis with novel topical therapies. J Dermatolog Treat. 2016;27(6):568-76.

23.Paller AS, Mancini AJ. Eczematous eruptions in childhood. In: Paller AS, Mancini AJ, editors. Hurwitz clinical pediatric dermatology. Philadelphia: Elsevier Saunders; 2006. p. 49-84.

24.Sathishkumar D, Moss C. Topical therapy in atopic dermatitis in children. Indian J Dermatol. 2016;61(6):656-61.

25.Angelova-Fischer I, Neufang G, Jung K, Fischer TW, Zillikens D. A randomized, investigator-blinded efficacy assessment study of stand-alone emollient use in mild to moderately severe atopic dermatitis flares. J Eur Acad Dermatol Venereol. 2014;28 Suppl 3:9-15.

26. Mahe YF, Perez MJ, Tacheau C, Fanchon C, Martin R, Rousset $\mathrm{F}$, et al. A new Vitreoscilla filiformis extract grown on spa waterenriched medium activates endogenous cutaneous antioxidant and antimicrobial defenses through a potential Toll-like receptor 2/protein kinase $\mathrm{C}$, zeta transduction pathway. Clin Cosmet Investig Dermatol. 2013;6:191-6.

27.Bianchi P, Theunis J, Casas C, Villeneuve C, Patrizi A, Phulpin $\mathrm{C}$, et al. Effects of a new emollient-based treatment on skin microflora balance and barrier function in children with mild atopic dermatitis. Pediatr Dermatol. 2016;33(2):165-71.

28. Tollefson MM, Bruckner AL, Section on Dermatology. Atopic dermatitis: skin-directed management. Pediatrics. 2014;134(6):e1735-44.

29.Devillers AC, Oranje AP. Efficacy and safety of 'wet-wrap' dressings as an intervention treatment in children with severe and/or refractory atopic dermatitis: a critical review of the literature. Br J Dermatol. 2006;154(4):579-85.

30.Wollenberg A, Bieber T. Proactive therapy of atopic dermatitis - an emerging concept. Allergy. 2009;64(2):276-8.

31.Meurer M, Eichenfield LF, Ho V, Potter PC, Werfel T, Hultsch T. Addition of pimecrolimus cream $1 \%$ to a topical corticosteroid treatment regimen in paediatric patients with severe atopic dermatitis: a randomized, double-blind trial. J Dermatolog Treat. 2010;21(3):157-66.

32.Schmitt J, von Kobyletzki L, Svensson A, Apfelbacher C. Efficacy and tolerability of proactive treatment with topical corticosteroids and calcineurin inhibitors for atopic eczema: Systematic review and meta-analysis of randomized controlled trials. Br J Dermatol. 2011;164(2):415-28.

33. Wollenberg A, Sidhu MK, Odeyemi I, Dorsch B, KoehneVolland R, Schaff M, et al. Economic evaluation of maintenance treatment with tacrolimus $0.1 \%$ ointment in adults with moderate to severe atopic dermatitis. $\mathrm{Br} \mathrm{J}$ Dermatol. 2008;159(6):1322-30.

34.Ruzicka T, Bieber T, Schöpf E, Rubins A, Dobozy A, Bos JD, et al. A short-term trial of tacrolimus ointment for atopic dermatitis. N Engl J Med. 1997;337(12):816-21.

35.Chen SL, Yan J, Wang FS. Two topical calcineurin inhibitors for the treatment of atopic dermatitis in pediatric patients: a meta-analysis of randomized clinical trials. J Dermatolog Treat. 2010;21(3):144-56.

36.Bornhövd EC, Burgdorf WHC, Wollenberg A. Immuno- 
modulatory macrolactams for topical treatment of inflammatory skin diseases. Curr Opin Investig Drugs. 2002;3(5):708-12.

37. Napadow V, Li A, Loggia ML, Kim J, Mawla I, Desbordes G, et al. The imagined itch: brain circuitry supporting nocebo-induced itch in atopic dermatitis patients. Allergy. 2015;70(11):1485-92.

38.Eberlein B, Eicke C, Reinhardt HW, Ring J. Adjuvant treatment of atopic eczema: assessment of an emollient containing N-palmitoylethanolamine (ATOPA study). J Eur Acad Dermatol Venereol. 2008;22(1):73-82.

39.Reimann S, Luger T, Metze D. Topische Anwendung von Capsaicin in der Dermatologie zur Therapie von Juckreiz und Schmerz. Hautarzt. 2000;51(3):164-72.

40.Drake LA, Fallon JD, Sober A. Relief of pruritus in patients with atopic dermatitis after treatment with topical doxepin cream. The Doxepin Study Group. J Am Acad Dermatol. 1994;31(4):613-6.

41.Stevens MT, Edwards AM. The effect of $4 \%$ sodium cromoglicate cutaneous emulsion compared to vehicle in atopic dermatitis in children - a meta-analysis of total SCORAD scores. J Dermatolog Treat. 2015;26(3):284-90.

42.Nakai K, Yoneda K, Murakami Y, Koura A, Maeda R, Tamai A, et al. Effects of topical N-acetylcysteine on skin hydration/ transepidermal water loss in healthy volunteers and atopic dermatitis patients. Ann Dermatol. 2015;27(4):450-1.

43.Silverberg JI, Nelson DB, Yosipovitch G. Addressing treatment challenges in atopic dermatitis with novel topical therapies. J Dermatolog Treat. 2016;27(6):568-76.

44.Jarnagin K, Chanda S, Coronado D, Ciaravino V, Zane LT, Guttman-Yassky E, et al. Crisaborole topical ointment, 2\%: a nonsteroidal, topical, anti-inflammatory phosphodiesterase 4 inhibitor in clinical development for the treatment of atopic dermatitis. J Drugs Dermatol. 2016;15(4):390-6.

45.Zane LT, Chanda S, Jarnagin K, Nelson DB, Spelman L, Gold LS. Crisaborole and its potential role in treating atopic dermatitis: overview of early clinical studies. Immunotherapy. 2016;8(8):853-66.

46.Zane LT, Kircik L, Call R, Tschen E, Draelos ZD, Chanda $S$, et al. Crisaborole topical ointment, $2 \%$ in patients ages 2 to 17 years with atopic dermatitis: A Phase 1b, Open-Label, Maximal-Use Systemic Exposure Study. Pediatr Dermatol. 2016;33(4):380-7.

47.Draelos ZD, Stein Gold LF, Murrell DF, Hughes MH, Zane LT. Post hoc analyses of the effect of crisaborole topical ointment, $2 \%$ on atopic dermatitis: associated pruritus from phase 1 and 2 clinical studies. J Drugs Dermatol. 2016;15(2):172-6.

48. Bissonnette R, Papp KA, Poulin Y, Gooderham M, Raman M, Mallbris L, et al. Topical tofacitinib for atopic dermatitis: a phase 2a randomized trial. Br J Dermatol. 2016;175(5):902-11.

49. Jacob SE, Castanedo-Tardan MP. Pharmacotherapy for allergic contact dermatitis. Expert Opin Pharmacother. 2007;8(16):2757-74.

50.De Benedetto A, Agnihothri R, McGirt LY, Bankova LG, Beck LA. Atopic dermatitis: a disease caused by innate immune defects? J Invest Dermatol. 2009;129(1):14-30.

51.Niebuhr M, Werfel T. Innate immunity, allergy and atopic dermatitis. Curr Opin Allergy Clin Immunol. 2010;10(5):463-8.

52.Darabi K, Hostetler SG, Bechtel MA, Zirwas M. The role of
Malassezia in atopic dermatitis affecting the head and neck of adults. J Am Acad Dermatol. 2009;60(1):125-36.

53.Mayser P, Kupfer J, Nemetz D, Schäfer U, Nilles M, Hort W, et al. Treatment of head and neck dermatitis with ciclopiroxolamine cream - results of a double-blind, placebocontrolled study. Skin Pharmacol Physiol. 2006;19(3):153-9.

54.Legat FJ, Wolf P. Cutaneous sensory nerves: mediators of phototherapeutic effects? Front Biosci (Landmark Ed). 2009; 14:4921-31.

55.Gambichler T, Kreuter A, Tomi NS, Othlinghaus N, Altmeyer P, Skrygan M. Gene expression of cytokines in atopic eczema before and after ultraviolet A1 phototherapy. Br J Dermatol. 2008;158(5):1117-20.

56.Hong SP, Kim MJ, Jung MY, Jeon H, Goo J, Ahn SK, et al. Biopositive effects of low-dose UVB on epidermis: coordinate upregulation of antimicrobial peptides and permeability barrier reinforcement. J Invest Dermatol. 2008;128(12):2880-7.

57.Hoare C, Li Wan Po A, Williams H. Systematic review of treatments for atopic eczema. Health Technol Assess. 2000;4(37):1-191.

58.Berth-Jones J, Takwale A, Tan E, Barclay G, Agarwal S, Ahmed I, et al. Azathioprine in severe adult atopic dermatitis: a doubleblind, placebo-controlled, crossover trial. $\mathrm{Br} \mathrm{J}$ Dermatol. 2002;147(2):324-30.

59.Nomura T, Kabashima K. Advances in atopic dermatitis in 2015. J Allergy Clin Immunol. 2016;138(6):1548-55.

60.Simpson EL, Bieber T, Guttman-Yassky E, Beck LA, Blauvelt A, Cork MJ, et al. Two phase 3 trials of dupilumab versus placebo in atopic dermatitis. N Engl J Med. 2016; 375(24):2335-48.

61.McNally NJ, Williams HC, Phillips DR, Smallman-Raynor M, Lewis S, Venn A, et al. Atopic eczema and domestic water hardness. Lancet. 1998;352(9127):527-31.

62.Horimukai K, Morita K, Narita M, Kondo M, Kitazawa $\mathrm{H}$, Nozaki M, et al. Application of moisturizer to neonates prevents development of atopic dermatitis. J Allergy Clin Immunol. 2014;134(4):824-30.

63.Epstein TG, Bernstein DI, Levin L, Khurana Hershey GK, Ryan PH, Reponen T, et al. Opposing effects of cat and dog ownership and allergic sensitization on eczema in an atopic birth cohort. J Pediatr. 2011;158(2):265-71.

64.Bindslev-Jensen C. Standardization of double-blind, placebocontrolled food challenges. Allergy. 2001;56 Suppl 67:75-7.

65.Bath-Hextall F, Delamere FM, Williams HC. Dietary exclusions for improving established atopic eczema in adults and children: systematic review. Allergy. 2009;64(2):258-64.

66.Saeki H, Nakahara T, Tanaka A, Kabashima K, Sugaya $\mathrm{M}$, Murota $\mathrm{H}$, et al. Clinical Practice Guidelines for the Management of Atopic Dermatitis 2016. J Dermatol. 2016;43(10):1117-45.

67.Madhok V, Futamura M, Thomas KS, Barbarot S. What's new in atopic eczema? An analysis of systematic reviews published in 2012 and 2013. Part 2. Treatment and prevention. Clin Exp Dermatol. 2015;40(4):349-54.

68.Foolad N, Brezinski EA, Chase EP, Armstrong AW. Effect of nutrient supplementation on atopic dermatitis in children: a systematic review of probiotics, prebiotics, formula, and fatty acids. JAMA Dermatol. 2013;149(3):350-5. 


\title{
Nacionalni vodič za terapiju atopijskog dermatitisa
}

\author{
Svetlana POPADIĆ ${ }^{1}$, Mirjana GAJIĆ VELJIĆ ${ }^{1}$, Sonja PRĆIĆ ${ }^{2}$ Željko MIJUŠKOVIĆ \\ Dragan JOVANOVIĆ ${ }^{3}$, Lidija KANDOLF SEKULOVIĆ ${ }^{4}$, Miloš NIKOLIĆ ${ }^{1}$
}

\begin{abstract}
${ }^{1}$ Klinika za dermatovenerologiju Klinički centar Srbije, Katedra za dermatovenerologiju, Medicinski fakultet Univerziteta u Beogradu

${ }^{2}$ Institut za zdravstvenu zaštitu dece i omladine Vojvodine, Medicinski fakultet Univerziteta u Novom Sadu

${ }^{3}$ Klinika za kožne i polne bolesti Klinički centar Niš, Katedra za dermatovenerologiju, Medicinski fakultet Univerziteta u Nišu

${ }^{4}$ Klinika za kožne i polne bolesti, Vojnomedicinska akademija, Medicinski fakultet, Vojnomedicinska akademija
\end{abstract}

Dopisni autor: Svetlana Popadić; e-pošta: spopadic@med.bg.ac.rs

UDK 616.5-002-08(061.2)

Epidemiološke karakteristike atopijskog dermatitisa Atopijski dermatitis (AD) je oboljenje koje obično počinje u ranom detinjstvu (1). AD je jedno od najčešćih oboljenja kože i javlja se kod približno $20 \%$ dece i $1-3 \%$ odraslih (2). Kod $60 \%$ pacijenata prve manifestacije se javljaju u prvoj godini života, a kod $90 \%$ obolelih do navršene pete godine. Kod većine pacijenata bolest se povlači do odraslog doba; kod $25 \%$ perzistira tokom života, dok se kod manjeg broja obolelih prve manifestacije AD pojavljuju u adultnom periodu (2). Približno četvrtina obolelih od AD razviće i neku formu ekcema na šakama tokom adultnog perioda (3).

\section{Klinička slika atopijskog dermatitisa}

Klinička slika se razlikuje u zavisnosti od životnog doba i toka bolesti, a glavni znaci su eritem, edem, erozije i ekskorijacije, vlaženje, kruste, suva koža i lihenifikacija (1, 4-7). Intenzivan svrab je karakterističan za $\mathrm{AD}$ i dovodi do nastanka ekskorijacija, prurigo papula, lihenifikacije i ekcematoznih kožnih lezija (2-4). Posebno je izražen noću, što onemogućava spavanje i značajno utiče na kvalitet života i pacijenta i porodice $(4,5,7,8)$. Promene na koži mogu biti akutnog, subakutnog i hroničnog tipa. Za akutne lezije su karakteristični: intenzivan svrab, eritem, pojedinačne i slivene papule (nekad i vezikule); prate ih ekskorijacije, erozije i serozni eksudat. Subakutne lezije se manifestuju kao eritematozne, ekskorisane papule sa skvamom, dok su za hronični tip promena tipična zadebljanja kože $s$ naglašenim kožnim crtežom (lihenifikacija) i prurigo papule. Kod odojčadi i mlađe dece, $\mathrm{AD}$ je pretežno akutnog i subakutnog toka, dok kod starije dece i odraslih poprima hronični oblik (5-7). Kod jednog pacijenta često su prisutne sve tri faze promena $(6,7)$.

\section{Klinička slika kod dece}

U prvom mesecu života, žućkaste, izražene skvame u kapilicijumu, poznate kao temenjača ili tzv. seboroični dermatitis odojčadi, mogu biti prvi znak atopijskog dermatitisa (1). U uzrastu odojčeta, od trećeg do šestog meseca života, predilekciono mesto za nastanak ekcemskih promena je lice (obrazi, čelo i brada), dok su centralni deo lica (nos, perioralna regija) i regija koju pokriva pelena (tzv. pelenska regija) najčešće pošteđeni. Promene na koži su akutnog i subakutnog toka, nejasno ograničene, u vidu eritema, edema, papulovezikula, ekskorijacija, često sa vlaženjem i krustama, ređe hronične u vidu eritematoznih papula i plakova sa skvamom. Od osmog do desetog meseca života, $\mathrm{AD}$ se širi na ekstenzorne strane ekstremiteta, a nakon prve godine života na gornji deo trupa, gde promene mogu imati numularan izgled $(1,5-7)$. Nakon druge godine života, klinička slika se menja prelaskom prethodne forme u hronični oblik, ili $\mathrm{AD}$ može nastati de novo. Javljaju se nejasno ograničeni lihenifikovani plakovi sa ekskorijacijama, lokalizovani u kubitalnim i poplitealnim pregibima, na vratu i u okolini ručnih i skočnih zglobova. Koža celog tela je suva. Lihenifikacija je posledica češanja, zbog izraženog, pretežno noćnog, svraba. Povremeno se na ovim lezijama razvijaju akutni ekcemski naleti u vidu papula i papulovezikula (1, 5-7). U adolescenciji perzistiraju lihenifikovani plakovi u pregibima velikih zglobova, uz nastajanje hroničnih 
promena na licu - periorbitalni dermatitis, zatim na vratu, šakama, stopalima i leđima $(5,7)$.

\section{Klinička slika kod odraslih}

Kod odraslih osoba, u kliničkoj slici dominiraju lihenifikovani plakovi, koji se obično nalaze u pregibima ekstremiteta i u anogenitalnoj regiji. Često je prisutan edem lica sa lihenifikacijom na vratu i očnim kapcima i hronični ekcem šaka i/ili stopala. Prurigo tip AD karakterišu ekskorisani pruriginozni čvorovi. Bolest ima hronično recidivirajući tok. Egzacerbacije bolesti često počinju sa izraženim svrabom bez vidljivih lezija, a kasnije se pojavljuje eritem, papule i infiltracija (1, 5-7).

Pacijenti sa $\mathrm{AD}$ pokazuju povećanu sklonost ka infekcijama kože, uglavnom bakterijskim ali i virusnim i gljivičnim $(5,6,7,9)$. Bakterijske infekcije najčešće izaziva Staphylococcus aureus, ređe Streptococcus pyogenes $(6,7)$. Virusne infekcije su češće kod obolelih od $\mathrm{AD}$, sa sklonošću ka diseminaciji i širenju promena $(1,8,10)$. U zavisnosti od virusa koji ih izaziva, može nastati eczema herpeticum, eczema molluscatum, eczema coxsackium ili eczema vaccinatum (1,9-11). Gljivična infekcija izazvana specijesom Malassezia sympodialis (Pityrosporum ovale) dovodi do nastanka takozvanog head and neck dermatitisa (12).

Za procenu težine kliničke slike $\mathrm{AD}$ kod dece $\mathrm{i}$ odraslih koriste se indeksi SCORAD (više u Evropi) i EASI (više u Severnoj Americi) (8).

\section{Etiopatogeneza atopijskog dermatitisa}

Etiopatogeneza AD je multifaktorska. Obuhvata defekt kožne barijere, imunsku reakciju sa ključnom ulogom T-ćelija, dendritičnih ćelija, limfoidnih ćelija, mastocita i eozinofila, kao i faktora sredine.

Disfunkcija barijere kože kod AD posledica je tri bitna faktora: defekta ekspresije gena za filagrin, smanjene količine ceramida u koži i povećane aktivacije epidermalnih proteaza. Skoro $50 \%$ pacijenata sa AD ima defekt ekspresije gena za sintezu filagrina, proteina koji ima ključnu ulogu u održavanju strukturne barijere kože, dok njegov nedostatak remećenjem ove strukture olakšava penetraciju haptena i proteina (13, 14). Ceramid je lipid važan za zadržavanje vode u kornealnom sloju epiderma.

Kod pacijenata sa $\mathrm{AD}$, u odnosu na zdrave osobe, identifikovano je značajno smanjenje količine ceramida u lezijama, ali i u neizmenjenoj koži. Dokazano je da je količina ceramida u epidermu u obrnutoj srazmeri sa transepidermalnim gubitkom vode, bitnom karakteristikom kože atopičara. Kod dece se međutim smanjena količina ceramida prema nekim autorima nalazi samo u lezionoj, a ne i u neizmenjenoj koži, što se objašnjava postinflamatornom reakcijom, a ne genetskom uslovljenošću $(13,14)$. U odnosu na imunske aspekte, patogeneza $\mathrm{AD}$ je veoma složena jer obuhvata sadejstvo urođenog istečenog imuniteta. Ćelije prisutne u koži, poput keratinocita, dendritičnih ćelija, mastocita, makrofaga i nezrelih limfocita, učestvuju u zapaljenskoj reakciji. Pored njih, u nastanku ekcemske reakcije takođe učestvuju T-limfociti, plazmocitoidne dendritične ćelije, monociti i granulociti iz cirkulacije (13, 14). U patogenezi AD, T-helper (pomoćnički) limfociti imaju centralnu ulogu. Kod bolesnika sa AD postoji neuravnoteženost aktivnosti specifičnih klonova pomoćničkih T-ćelija, sa predominacijom TH2 tipa ćelijskog odgovora na alergene, za razliku od normalnih osoba gde dominira TH1 tip. Patološka aktivacija TH2 ćelija vodi pojačanoj produkciji IL-4, IL-5 i IL-13, što ima za posledicu nakupljanje drugih tipova imunskih ćelija i razvoj akutnih lezija kod AD. Za razliku od akutnih, u hroničnim lezijama $\mathrm{AD}$ dominira $\mathrm{TH} 1$ ćelijska aktivnost $(13,14)$.

Razlika u incidenciji i prevalenciji $\mathrm{AD}$ u različitim geografskim oblastima ukazuje i naznačajnu ulogu faktora sredine u etiopatogenezi, poput klimatskih faktora, faktora ishrane, gojaznosti, izloženosti duvanskom dimu i drugim zagađivačima okoline, kao i mikrobiološkoj izloženosti. Novija istraživanja naglašavaju ulogu i uticaj mikrobioma kože, kako na njenu homeostazu tako i na pojavu različitih patoloških stanja, uključujući i $A D$. U epizodama pogoršanja kliničke slike kod $\mathrm{AD}$ evidentno je povećanje količine $S$. aureus, ali i $S$. epidermidis. Egzacerbacija kutane inflamacije posredovana je superantigenima poput stafilokoknih enterotoksina A i B, kao i dejstvom toksičnog šok-simptom toksina 1 koji dovodi do poliklonske aktivacije T-ćelija $(13,14)$. Ustanovljeno je da povećana ekspozicija UV zracima i toploti deluju protektivno na pojavu ekcema, nasuprot smanjenoj ekspoziciji UV zracima i povećanoj vlažnosti vazduha $(13,14)$. Kiseli $\mathrm{pH}$ kože doprinosi barijernoj funkciji, jer ima antibakterijsko dejstvo i ulogu u deskvamaciji. Pokazano je da je kod pacijenata sa AD $\mathrm{pH}$ čitave kože povećan, što dovodi do egzacerbacije bolesti, a najčešći faktori koji dovode do remećenja $\mathrm{pH}$ 
kože su deterdženti i sapuni. Time se remeti sadržaj lipida na površini kože, pojačava dejstvo proteaza i istanjuje kornealni sloj epiderma $(13,14)$. Veoma je složena interakcija ranije navedenih genetskih faktora, imunskih faktora i faktora sredine u etiopatogenezi $\mathrm{AD}$ i, uz brojna aktuelna saznanja, predstavlja veliki izazov za buduća istraživanja koja bi ponudila nove i preciznije odgovore na mnoga, još uvek nedovoljno razjašnjena pitanja.

\section{Dijagnostički kriterijumi za atopijski dermatitis}

Evropska radna grupa za atopijski dermatitis (engl. Europan Task Force on Atopic Dermatitis) definisala

Tabela 1. Dijagnostički kriterijumi za atopijski dermatitis (15)

\section{Major (tri od četiri)}

- Pruritus

- Dermatitis koji zahvata fleksorne površine kod dece starije od dve godine i odraslih ili lice u prvoj godini

- Hronični ili hronično-recidivirajući tok bolesti

- Lična i porodična anamneza o atopiji

\section{Minor (najmanje tri)}

- Pozitivni prik kutani testovi (I tip preosetljivosti)

- Povećana ukupna koncentracija IgE u serumu

- Pojava bolesti u najranijem detinjstvu

(kod 90\% pre pete godine)

- Suvoća kože

- Bledilo i/ili eritem lica

- Pityriasis alba

- Ihtioza

- Tamni podočnjaci

- Deni-Morganovi (Dennie-Morgan)

infraorbitalni nabori

- Hiperlinearnost dlanova

- Keratosis pilaris

- Heilitis

- Ekcem šaka i stopala

- Ekcem areola dojki

- Svrab prilikom znojenja

- Nepodnošenje vune

- Beli dermografizam

- Perifolikularna akcentuacija

- Nabori prednje strane vrata

- Supkapsularna katarakta i keratokonus

- Sklonost bakterijskim i virusnim infekcijama kože (S. aureus, HSV)

- Smanjen ćelijski posredovan imunski odgovor

- Pogoršanje promena na koži pod uticajem

emocionalnih faktora, faktora sredine i iritanasa

- Preosetljivost na hranu, naročito kod dece mlađe od dve godine 
je atopiju kao „porodičnu sklonost ka razvoju Th2 imunskog odgovora na uobičajene antigene okoline" sa razvojem tipičnih bolesti - atopijskog dermatitisa, astme, i/ili alergijskog rinitisa. Dijagnoza, atopijskog dermatitisa postavlja se pre svega na osnovu anamnestičkih podataka i karakteristične kliničke slike, a proteklih decenija razvijani su različiti dijagnostički kriterijumi čija je pouzdanost različita. Dijagnostički kriterijumi su neophodni, pre svega, u epidemiološkim i kliničkim studijama koje moraju imati precizno definisane kriterijume za uključenje pacijenata $(1,15,16)$.

Dijagnostički kriterijumi za atopijski dermatitis većinom uključuju kliničke znake i delom rezultate alergoloških i laboratorijskih testiranja kojima se dokazuje atopija. Istorijski najpoznatiji i najviše korišćeni u svakodnevnoj kliničkoj praksi su kriterijumi Hanifina i Rajke - Tabela 1 (15). Prema ovim kriterijumima, za dijagnozu je potrebno tri od četiri major kriterijuma i tri minor kriterijuma. Ovi dijagnostički kriterijumi validirani su u dve studije u kojima je njihova dijagnostička senzitivnost bila 87,9\% i $96 \%$, a specifičnost $77,6 \%$ i $93 \%$ (16).

Drugi, manje korišćeni kriterijumi su britanske radne grupe (engl. UK Working Party) kriterijumi koji podrazumevaju da se atopijski dermatitis dijagnostikuje na osnovu prisustva promena na koži u poslednjih 12 meseci i još najmanje 3 od sledećih kriterijuma: pojava promena na koži pre druge godine života (ne primenjuje se kod dece mlađe od 4 godine), anamneza o zahvatanju fleksornih površina ili prisustvo ovakvih promena na pregledu, suvoća kože i lična anamneza o drugim atopijskim bolestima (ili porodična anamneza za decu mlađu od 4 godine) (17). Ovi kriterijumi su validirani u najvećem broju studija, a specifičnost je varirala $10-100 \%$, a senzitivnost $89-99 \%$.

Takođe, Američka akademija za dermatologiju predložila je svoje kriterijume koji su podeljeni u obavezne, značajne i udružene kriterijume u odnosu na njihovu učestalost i dijagnostičku važnost (18). Nekoliko drugih dijagnostičkih kriterijuma takođe je objavljeno, ali nisu našli primenu u svakodnevnoj praksi $(19,20)$.

Nedavnom analizom i sistematskim pregledom studija koje su validirale različite dijagnostike kriterijume utvrđeno je da je metodologija ovih validacija veoma različita što onemogućava konačne zaključke (16).

\section{Lokalna terapija i nega kože Emolijentna terapija i nega kože}

Lečenje $\mathrm{AD}$ zahteva efikasnu kontrolu akutnih simptoma i znakova bolesti, obnavljanje funkcije barijere kože i izbegavanje faktora sredine koji pokreću i pogoršavaju bolest. Pojedina sredstva za hidriranje kože poboljšavaju barijernu funkciju kože i smanjuju osetljivost kože na iritanse $(21,22)$.

\section{Pranje i kupanje}

Suvoća kože je više izražena tokom hladnih meseci zbog suvog toplog vazduha i niske vlažnosti u stanovima. Kupanje svakog dana se smatra jednim od najboljih načina hidriranja kože. Koža se mora prati temeljno, ali nežno i pažljivo, kako bi se uklonili skvama i kruste sa površine, iritansi i alregeni i obezbedila mogućnost za hidriranje kože. Voda treba da bude topla, a optimalna dužina boravka u vodi je do 20 minuta. Kratkotrajnim kupanjem (samo $5 \mathrm{~min}$ ), uz upotrebu uljane kupke (poslednja 2 minuta tuširanja), može se izbeći dehidracija epiderma $(8,23)$. Sapuni, šamponi i gelovi za tuširanje koji stvaraju penu treba da se izbegavaju jer iritiraju i isušuju kožu. Kod dece u prepubertetskom sebumu se ne produkuje, tako da je potrebna minimalna količina šampona. Uljane kupke mogu imati efekat hidriranja, ali su dokazi o njihovoj efikasnosti nedovoljni. $\mathrm{Na}$ tržištu su dostupna neutralna ili sredstva za pranje sa fiziološkim pH koja su hipoalergogena i bez mirisa, ali se kao zamena za sapun mogu primenjivati i kremovi i losioni koji hidriraju tako što će se naneti na kožu pre kupanja ili tuširanja i umasirati u kožu tokom kupanja $(19,24)$. Poželjno je nanošenje emolijenasa odmah nakon kupanja i brisanja kože, dok je koža još uvek vlažna. Najbolji način za održavanje vlažnosti kože kod pacijenata sa $\mathrm{AD}$ je nanošenje debljeg sloja emolijensa tokom prva 3 minuta posle kupanja, pre nego što dođe do isušivanja kože $(8,22,23)$.

\section{Emolijentna terapija}

Pravilna upotreba emolijenasa za hidriranje je ključna u lečenju pacijenata sa AD. Emolijensi predstavljaju osnovu terapije održavanja. Dostupni su u različitim oblicima. Losioni su retke konzistencije sa visokim sadržajem vode, korisni su za regije obrasle dlakom i za ekcem sa vlaženjem, ali su neefikasni kod izražene kseroze. Kremovi (emulzije vode i ulja) najčešće se 
primenjuju jer se lako nanose, ne ostavljaju sjajan trag, ali su masniji od losiona. Pojedina ulja se zgušnjavaju u hladnijim klimatskim uslovima, ali postaju ređa na temperaturi tela. Masti su guste, mogu se naneti u debelom sloju i pogodne su za veoma suv ekcem. Međutim, manje su kozmetički prihvatljive, mogu da izazovu pretopljavanje i folikulitis i mogu da ostavljaju mrlje na odeći i posteljini. Aditivi mogu da izazovu iritaciju ili alergijske reakcije, a najbolje je da emolijensi koji se koriste za atopičare budu bez parfema (24).

Pacijente treba podsticati da probaju različite emolijense, ali i preporučiti odgovarajuće u zavisnosti od njihovog tipa kože, načina života i klimatskih uslova u kojima žive. Hidriranje kože se obično postiže nanošenjem preparata za hidriranje najmanje dva puta dnevno. Pacijenti mogu primenjivati emolijense na bazi krema tokom dana i toplog vremena, a masti tokom noći i hladnog vremena. Često se ne upotrebljava dovoljna i potrebna količina emolijentnog preparata. Kod odraslih pacijenata sa generalizovanim ekcemom potrebno je približno $600 \mathrm{~g}$ emolijensa nedeljno, a kod dece $250 \mathrm{~g}$ nedeljno. U toku hladnijih meseci u godini, emolijense je potrebno primenjivati više puta dnevno, a najvažnija je primena na vlažnu kožu, posle kupanja. Treba da se nanose na celu kožu, ne samo na zahvaćene zone, i da se utrljaju u kožu u smeru rasta dlake kako bi se izbegao nastanak folikulitisa $(19,24)$.

Upotreba emolijenasa je široko preporučena za lečenje AD, posebno između recidiva. Potrebno je prvo primeniti diferentno terapijsko sredstvo na lezije, a tek kasnije, na celu površinu kože, emolijentni krem (8). Ako se emolijensi nanose posle primene lokalnih kortikosteroida, savetuje se da prođe 15-20 minuta od aplikacije leka, a ukoliko se primenjuju posle topikalnih kalcineurinskih inhibitora, savetuje se da prođe 30-ak minuta od primene leka. Redovna upotreba emolijenasa ima kratkoročne i dugoročne steroid sparing (ušteda kortikosteroida) efekte kod pacijenata sa blagim do umereno teškim $\mathrm{AD}$. Da bi se postigla remisija, prvo je potrebna primena lokalnih kortikosteroida (kratkotrajna terapija). Održavanje stabilne remisije (dugoročna terapija održavanja) može se kod jednog broja pacijenata postići primenom emolijenasa dva puta nedeljno ili češće, nakon postizanja remisije topikalnim kortikopreparatima. Čak nanošenje emolijensa jedan put nedeljno može biti korisno za poboljšanje blagih do umereno teških lokalizovanih recidiva AD (25).
Poremećaj ravnoteže epidermalne mikroflore verovatno igra jednu od ključnih uloga u egzacerbaciji AD. Nanošenje novih tipova emolijenasa koji sadrže ekstrakt nepatogenih gram-negativnih bakterija dva puta dnevno štiti kožu od proliferacije patogenog stafilokoka i omogućava očuvanje raznolikosti mikroflore $(26,27)$.

\section{Lokalna antiinflamatorna terapija}

Efikasna lokalna terapija se oslanja na tri osnovna principa: dovoljna jačina, odgovarajuće doziranje i pravilna primena. Topikalnu terapiju uvek treba aplikovati na hidriranu kožu, posebno kada se primenjuju antiinflamatorni preparati u obliku masti. Topikalni kortikosteroidi (TKS) i imunomodulatori predstavljaju terapiju prvog reda za recidiv bolesti, dok se dugoročna terapija bazira na primeni emolijenasa koji poboljšavaju vlažnost kože, održavaju integritet epidermalne barijere, smanjuju intenzitet pruritusa i sprečavaju novi recidiv (28). Pacijenti sa akutnim ekcemom sa vlaženjem i erodovanim lezijama, posebno deca, ponekad ne tolerišu standardnu lokalnu terapiju, tako da se mogu prvo tretirati vlažnim oblogama (engl. wet wraps) dok se vlaženje ne zaustavi. Vlažne obloge su veoma efikasne kod akutnog ekcema i poboljšavaju toleranciju (29). I bez vlažnih obloga, topikalna terapija zahteva dosta vremena: pacijenti treba da planiraju 30 minuta za jednu aplikaciju lokalne terapije. Kako bi se postigao pozitivan efekat, jedan dobro sproveden tretman dnevno je obično dovoljan, osim kod akutnog ekcema sa vlaženjem koji zahteva nekoliko dana sa češćim nanošenjem lokalne terapije (8).

Uobičajeno se antiinflamatorna lokalna terapija nanosi samo na kožu sa promenama, a kada se vidljive promene izgube, aplikovanje se postepeno proređuje. Ovaj tradicionalni, reaktivni pristup se poslednjih godina zamenjuje proaktivnim konceptom lečenja, koji se definiše kao kombinacija unapred definisane, dugotrajne antiinflamatorne terapije malim dozama na prethodno zahvaćenim područjima kože u kombinaciji sa slobodnom upotrebom emolijenasa na celo telo i unapred određenim rasporedom kontrolnih kliničkih pregleda (30). Proaktivni postupak lečenja, koji se sprovodi obično dva puta nedeljno, počinje nakon uspešnog tretiranja svih lezija intenzivnom terapijom, obično aplikovanom dva puta dnevno, pored redovne emolijentne terapije prethodno neizmenjene kože (8). 


\section{Topikalni kortikosteroidi}

Topikalni kortikosteroidi (TKS) najvažniji su antiinflamatorni lekovi koji se koriste u terapiji AD, posebno u akutnoj fazi. Preporučuju se pacijentima sa AD kod kojih pravilna nega i upotreba emolijenasa nije dovela do pozitivnog odgovora. Pri izboru TKS preparata u obzir treba uzeti godine pacijenta, zahvaćenu regiju, stepen kseroze kože, želje pacijenta i cenu preparata. Topikalni kortikosteroidi predstavljaju terapiju prvog reda koja se primenjuje na inflamiranu kožu u zavisnosti od potrebe (pruritus, poremećaj sna, nove promene) $(8,18,22)$. Preporučuje se aplikacija TKS dva puta dnevno, mada i jednodnevna primena može biti dovoljna (25). Nije dokazana veća efikasnost ukoliko se aplikuju češće od dva puta dnevno. Apsorpcija je bolja ukoliko je koža hidrirana. Najbolji trenutak aplikovanja TKS je posle kupanja, 15-20 minuta pre nanošenja emolijensa.

Svrab je glavni simptom koji služi za procenu odgovora na terapiju. Snižavanje doziranja TKS ne bi trebalo započeti pre nestanka pruritusa i treba da bude postepeno kako bise izbegao reboundfenomen. Strategija snižavanja doze sastoji se od svakodnevne upotrebe slabije potentnih kortikosteroida ili nastavka primene potentnijih TKS, uz smanjivanje učestalosti primene (intermitentni režim) (8). Proaktivna, intermitentna upotreba TKS se preporučuje na područjima gde su recidivi česti $(18,22)$. Treba razmotriti mogućnost razvoja neželjenih efekata. Potrebno je praćenje u smislu nastanka neželjenih efekata tokom dugotrajne primene potentnih TKS. Kod pacijenata sa AD blage aktivnosti, mala količina TKS primenjena dva do tri puta nedeljno (mesečno $15 \mathrm{~g}$ kod beba, $30 \mathrm{~g}$ kod dece, 60-90 g kod adolescenata i odraslih), uz odgovarajuću primenu emolijenasa, obično omogućava dobro održavanje remisije sa SCORAD indeksom ispod 15-20. Ove mesečne količine, čak i potentnih TKS, obično nemaju negativne sistemske ili lokalne efekte (8). Kombinacija TKS istovremeno sa topikalnim kalcineurinskim inhibitorima najverovatnije nema koristan efekat u lečenju AD (31). Količina topikalnog antiinflamatornog preparata koja se nanosi treba da bude određena pravilom koje koristi „vrh-prsta jedinicu“ (engl. finger-tip unit, FTU). FTU je količina masti koja se istisne iz tube pomoću mlaznice prečnika $5 \mathrm{~mm}$ i meri se od distalnog interfalangealnog zgloba do vrha kažiprsta. Jedna FTU odgovara približno 0,5g i trebalo bi da bude dovoljna za pokrivanje površine koja odgovara površini oba dlana $(8,24)$.

\section{Topikalni kalcineurinski inhibitori}

Topikalni kalcineurinski infibitori (TKI) su imunosupresivni agensi koji inhibiraju kalcineurin u koži, blokirajući ranu T-ćelijsku aktivaciju i oslobađanje citokina. Oni su efikasni u redukovanju inflamacije kod AD. U Velikoj Britaniji, takrolimus $0,03 \%$ mast i pimekrolimus $1 \%$ krem su odobreni za upotrebu kod dece od dve do 15 godina, a takrolimus $0,1 \%$ mast kod dece starije od 16 godina $(28,32)$. U Evropskoj uniji oba TKI su odobrena od druge godine života (8). U Srbiji, takrolimus $0,03 \%$ mast i pimekrolimus $1 \%$ krem su odobreni za decu stariju od dve godine. TKI se preporučuju za kratkotrajnu, dugoročnu i terapiju održavanja $\mathrm{AD}$ kod odraslih i dece. Oni su poželjni u situacijama kada su kortikosteroidi kontraindikovani, na osetljivim regijama, zonama sa atrofijom usled primene steroida i ukoliko bi bila potrebna dugotrajna kontinuirana upotreba TKS. Posebno su korisni za regije gde je koža već tanka kao što su lice i pregibi. TKI se preporučuju kao steroid-sparing agensi. Kod pacijenata mlađih od dve godine sa blagim do teškim oblicima $\mathrm{AD}$, može se preporučiti tzv. off-label (zvanično neodobrena za ovaj uzrast) primena TKI. Proaktivna, intermitentna upotreba TKI takođe se preporučuje na područjima gde su recidivi najčešći $(18,22)$. Proaktivna terapija pomoću takrolimus masti aplikovane dva puta nedeljno sigurna je i efikasna do godinu dana trajanja, za redukciju broja relapsa i poboljšanje kvaliteta života odraslih pacijenata i dece sa $\mathrm{AD}(33)$.

Potrebno je uzeti u obzir mogućnost nastanka neželjenih efekata, uključujući osećaj peckanja i svraba, i o njima informisati pacijenta. Najčešće uočen sporedni efekat je prolazna toplotna senzacija na mestu aplikacije tokom prvih dana primene $(34,35)$. Počinje obično pet minuta nakon aplikacije, može trajati do jedan sat, ali se intenzitet i dužina trajanja obično smanjuju do potpunog nestanka tokom jedne nedelje (36). Pacijentima koji primenjuju TKI se preporučuje efikasna zaštita od sunca. Nema značajne sistemske apsorpcije TKI. TKI se primenjuju kod dece duže od 15 godina i nema dokaza o povećanom broju maligniteta (24). 


\section{Topikalna antipruriginozna terapija}

Postoji mali broj specifičnih i efikasnih antipruriginoznih sredstava za svrab kod ekcema (37). TKS se zbog svog antipruriginoznog dejstva mogu primenjivati $u$ inicijalnoj fazi egzacerbacije $A D$. Takođe, TKI značajno smanjuju pruritus kod AD već posle prvih nekoliko dana terapije i kod odraslih i kod dece.

\section{Specifična topikalna antipruriginozna terapija}

Topikalni anestetici (benzokain, lidokain, polidokanol, kombinacija prilokaina i lidokaina) kratkotrajno mogu smanjiti osećaj pruritusa kod AD (8). Agonisti kanabinoidnih receptora (N-palmitoiletanolamin, aplikovan dva puta dnevno) mogu uticati na smanjenje pruritusa i bola (38). Kapsaicin je prirodni alkaloid koji svoje funkcije ostvaruje preko kapsaicinspecifičnih receptora, lokalizovanih na slobodnim nervnim završecima. Postoje preliminarni dokazi o pozitivnom učinku kapsaicina kod pruritusa kod AD (39). Topikalni doksepin (5\% krem) ispoljava korisne efekte u smanjenju pruritusa kod AD (40). Međutim, ovaj preparat nije registrovan i nije $u$ upotrebi u evropskim zemljama zbog povećanog rizika od kontaktne preosetljivosti. Topikalni stabilizator mastocita natrijum-kromoglikat i inhibitori degranulacije mastocita smanjuju SCORAD indeks (41). Drugi novi lokalni preparati uključuju i tiolski derivat $\mathrm{N}$-acetilcistein, ali do sada ne postoje ubedljivi dokazi o efikasnosti kod $\mathrm{AD}$ (42). U sadašnjem momentu nema dovoljno dokaza randomiziranih kliničkih studija koji bi podržali upotrebu ovih preparata u terapiji pruritusa kod AD. Nijedan od ovih preparata nije registrovan u Evropi i ne preporučuje se njihova rutinska klinička upotreba kao pomoćna antipruriginozna terapija kod $\mathrm{AD}(8)$.

\section{Drugi antiinflamatorni agensi}

Razvoj specifične antiinflamatorne terapije koja je jednostavna za upotrebu i deluje na pruritus može obezbediti klinički značajan napredak u lečenju pacijenata sa $A D$. Većina novih terapijskih preparata se bazira na inhibiciji fosfodiesteraze 4 (PDE4), enzima čiji je nivo povišen kod inflamatornih poremećaja kao što je $\mathrm{AD}(43)$.

Krisaborol 2\% mast (ranije poznat kao AN2728) je benzoksaborol, nesteroidni topikalni antiinflamatorni inhibitor PDE4. Inhibicijom PDE4 i povećanjem nivoa cAMP, krisaborol kontroliše inflamaciju. Kada dospe u sistemsku cirkulaciju posle topikalne aplikacije, metaboliše se u inaktivne metabolite. Ovo ograničava sistemsko prisustvo krisaborola i sistemsku PDE4 inhibiciju. Krisaborol $2 \%$ mast se uglavnom dobro toleriše i popravlja indeks težine $\mathrm{AD}$, pruritus i sve druge znake i simptome $\mathrm{AD}$. Dve velike randomizirane kontrolisane kliničke studije (faza 3) koje su procenjivale efikasnost i bezbednost krisaborol 2\% masti kod dece, adolescenata i odraslih sa blagim i umerenim $\mathrm{AD}$ su nedavno završene pozitivnim ishodom (44-47).

Tofacitinib je inhibitor malog molekula Janus kinaze (JAK) koji utiče na interleukin (IL)-4, IL-5 i IL-31 signalne puteve, menjajući imunski odgovor koji dovodi do inflamacije. Tofacitinib 2\% mast, aplikovana dva puta dnevno tokom četiri nedelje, pokazuje značajnu efikasnost i bezbednost/lokalnu podnošljivost u ranoj fazi AD. JAK inhibicija, ostvarena preko topikalnog dejstva, predstavlja potencijalno obećavajući terapijski princip za $\mathrm{AD}$ (48).

\section{Opšta terapija atopijskog dermatitisa}

$S$ obzirom da se radi o hroničnom inflamatornom oboljenju, primena opšte kortikosteroidne terapije nije opravdana zbog kratkotrajnih i tranzijentnih pozitivnih efekata i potencijalnih neželjenih efekata.

U fazama pogoršanja opravdana je upotreba peroralnih $\mathrm{H} 1$ antihistaminika (zbog svraba), kao i cefalosporina ili makrolida per os (u slučaju bakterijske infekcije). Kod teških, generalizovanih i rezistentnih formi $\mathrm{AD}$, savetuje se i terapija ciklosporinom per os, a posle druge godine života u terapiju je moguće uvesti i metotreksat.

Antihistaminici. $\mathrm{H}-1$ antihistaminici za sistemsku primenu su bezbedni lekovi i tokom duže primene. Iako postoje mišljenja da nesedirajući antihistaminici nemaju adekvatan uticaj na smanjenje pruritusa kod obolelih od AD, savremeni terapijski protokoli i naša iskustva ukazuju da sistemska terapija antihistaminicima kod znatnog broja pacijenata umanjuje pruritus, poboljšava lokalni status na koži i pozitivno utiče na kvalitet života obolelih od AD.

$\mathrm{H} 1$ antihistaminici, blokadom $\mathrm{H} 1$ receptora dovode do blokade odgovora posredovanog aktivacijom $\mathrm{H} 1$ receptora i na taj način inhibiraju 
oslobađanje medijatora iz mast-ćelija i bazofila. Supresija inflamatornog odgovora postiže se smanjenjem prezentacije antigena i hemotakse, smanjenom ekspresijom ćelijskih adhezivnih molekula i smanjenjem nivoa proinflamatornih citokina (49). Oralni antihistaminici ublažavaju pruritus u $\mathrm{AD}$. Sedativni antihistaminici pored navedenog olakšavaju spavanje tokom noći koje je značajno poremećeno zbog pruritusa (49). Antihistaminici se koriste jednom ili više puta dnevno, prema preporuci proizvođača.

Hloropiramin, poredantipruriginoznog, ispoljava i lokalno anestetičko i vazokonstriktorno dejstvo kao i centralno sedativno dejstvo. Kontraindikovana je primena kod trudnica, novorođenčadi i nedonoščadi kao i kod žena u periodu laktacije s obzirom da se izlučuje i putem mleka. Kod dece se primena ovog leka savetuje samo u slučaju teških alergijskih reakcija. $\mathrm{Ne}$ savetujemo ga u terapiji $\mathrm{AD}$ u pedijatrijskom uzrastu. Kod odraslih pacijenata treba biti posebno oprezan ukoliko postoji povećana osetljivost na sedativne efekte antihistaminika i komorbiditeti kako što su epilepsija, hipertiroidizam i dr. Primenjuju se 1-3 ampule tokom $24 \mathrm{~h}$ kao duboka intramuskularna ili spora intravenska injekcija.

Noviji nesedativni antihistaminici (loratadin, desloratadin, cetirizin, levocetirizin i dr.) nalaze se u formi tableta i oralnih rastvora, komforni su i bezbedni za dugotrajnu primenu. Prema preporuci proizvođača, koriste se u jednoj dozi (1 x $1 \mathrm{tbl} / \mathrm{dn})$, međutim, u dermatologiji su opravdane i primene do četiri puta veće doze. Desloratadin oralni rastvor može da se primenjuje od šestog meseca života dok se upotreba levocetirizina savetuje od druge godine života. Pored dejstva na $\mathrm{H} 1$ receptore, oralni antihistaminici ispoljavaju i antiinflamatorna dejstava tako da višestruko utiču na poboljšanje znakova i simptoma AD.

Antibiotici. Antibiotici (cefalosporini i makrolidi) imaju značajno mesto u opštoj terapiji $\mathrm{AD}, \mathrm{u}$ fazama pogoršanja. Pored toga što narušena funkcija barijere epiderma kod pacijenata sa $\mathrm{AD}$ olakšava nastanak i razvoj infekcije, pruritus i češanje doprinose diseminaciji bakterije Staphylococcus aureus na inflamirane ali i na i neinflamirane delove kože. Sam $S$. aureus superantigenskom stimulacijom doprinosti razvoju i održavanju inflamacije kod pacijenata sa $\mathrm{AD}$ $(50,51)$. U fazama pogoršanja, cefaleksin smatramo lekom izbora, dok azitromicin može da se ordinira pacijentima preosetljivim na peniciline i cefalosporine.

Antimikotici. Pored značajne uloge bakterijskih infekcija u pokretanju inflamatorne kaskade i pogoršanja $A D$, gljivične infekcije takođe mogu da budu udružene sa razvojem i održavanjem inflamacije kod obolelih od AD. Antimikotici se savetuju kod tzv. head and neck varijante $\mathrm{AD}$ koja je često udružena sa superinfekcijom gljivicom Malassezia sympodialis (52). Opšta terapija ketokonazolom ili itrakonazolom i lokalna terapija ciklopiroksolaminom ili imidazolskim topikalnim antimikoticima (mikonazol, klotrimazol), tokom 7-14 dana, poboljšava nalaz, odnosno umanjuje inflamaciju kod pacijenata kod kojih su pretežno zahvaćeni glava i vrat (53). Drugi sistemski imidazolski preparati (flukonazol) takođe se sa uspehom koriste kod ove varijante AD. Po supresiji (super)infekcije gljivicama iz roda Malassezia, potrebno je nastaviti sa lokalnom (eventualno i sistemskom) antiinflamatornom terapijom, u skladu sa kliničkim nalazom.

Antivirusni lekovi. Virusne infekcije, pre svega molluscum contagiosum i infekcija Herpes simpex virusom lakše se diseminuju kod obolelih od AD. Eczema herpeticum se praktično javlja samo kod obolelih od AD i može da bude životno ugrožavajuća infekcija, posebno kod pacijenata u pedijatrijskom uzrastu. Terapija izbora kod molluscum contagioszum je primena tečnog azota i kiretiranje promena, dok je sistemski dat aciklovir lek izbora za eczema herpeticum (10).

Fototerapija. Tokom sunčanih meseci, AD se poboljšava kod većine pacijenata. Arteficijalni UV zraci (UVA i UVB fototerapija) imaju značajnu ulogu $\mathrm{u}$ lečenju obolelih od $\mathrm{AD}$, u našim krajevima posebno tokom perioda kasne jeseni i zime. Ustanovljeno je da UV zraci povoljno utiču na senzornu inervaciju kože (54), indukuju apoptozu u ćelijama inflamatornog infiltrata i smanjuju produkciju citokina koji doprinose fazama pogoršanja (55), poboljšavaju regenerišu barijernu funkciju kože (56) i drugo.

Trenutno su dostupni sledeći vidovi lampi:

Broadband UV (UVA + UVB = 290-400 nm),

Broadband ultraviolet $\mathrm{B}(\mathrm{BB}-\mathrm{UVB}=280-315 \mathrm{~nm})$,

Narrow-band UVB (nbUVB = peak: $311-313 \mathrm{~nm})$, UVA1 (340-400 nm).

Fototerapija se najčešće uvodi ukoliko se ne 
postižu zadovoljavajući efekti primenom optimalne lokalne terapije i odlična je kao terapija održavanja. Retko se koristi kao monoterapija u fazama pogoršanja. PUVA terapija se ne savetuje kod pacijenata mlađih od 12 godina. Generalno, zavisno od izgleda kabine u kojoj se nalaze UV lampe i saradnje samog pacijenta, individualno se procenjuje mogućnost započinjanja UVB fototerapije kod mlađih pacijenata. Retko je primena ovog vida terapije, uz asistenciju medicinskih radnika ili roditelja (ukoliko u kabini za UVB fototerapiju ima prostora za dete i odraslu osobu), moguća pre pete-šeste godine života. Tokom sunčanih meseci, savetuje se kontrolisana fotoekspozicija.

Ciklosporin. Ciklosporin ostvaruje dejstvo sprečavanjem produkcije IL-2. Rezultati metaanalize (57) potvrdili su efikasnost ciklosporina u terapiji AD. Ciklosporin dovodi do kliničkog poboljšanja, poboljšanja sna i umanjuje potrebu za lokalnom kortikosteroidnom terapijom. Po isključivanju ciklosporina mogući su brzi recidivi. Pre uvođenja ciklosporina u terapiju neophodna je kontrola arterijske tenzije, nivoa kreatinina $u$ serumu kao i osnovne biohemijske analize krvi i urina. Ciklosporin se primenjuje $2,5-5 \mathrm{mg} / \mathrm{kg}$ telesne mase dnevno, podeljeno u dve doze (na $12 \mathrm{~h}$ ). Savetuje se započinjanje terapije nižim dozama ciklosporina, a zatim, uz kontrolu bubrežne funkcije, nivoa ciklosporina u serumu i kontrolu arterijske tenzije, podizanje doze do $5 \mathrm{mg} / \mathrm{kg}$. Nije opravdano ordinirati više od $5 \mathrm{mg} / \mathrm{kg}$ zbog povišenog rizika od razvoja nefrotoksičnih efekata.

Metotreksat. Metotreksat (MTX) takođe se sa uspehom koristi u lečenju težih formi AD. Primena metotreksata se ne preporučuje pre druge godine života. Pre uvođenja MTX u terapiju kontroliše se KKS, kreatinin, AST, ALT, kao i nalaz urina. Inicijalno je značajno uraditi virusološke analize (HBsAg i antiHCV ukupni). Probna doza MTX ordinira se 5-7 dana pre ordiniranja prve, pune terapijske doze leka. Kod pedijatrijskih pacijenata, do 4-5. godine života probna doza može da iznosi $1,25 \mathrm{mg}(1 / 2 \mathrm{tbl})$ dok kod starijih i odraslih pacijenata probna doza iznosi $2,5 \mathrm{mg}$ ( $1 \mathrm{x}$ $1 \mathrm{tbl}$ ). Posle 5-7 dana kontrolišu se KKS, hepatogram i sediment urina $i$, ukoliko su nalazi uredni, smatra se da se može započeti sa terapijskim dozama MTX. Inicijalna doza kod pedijatrijskih pacijenata iznosi $0,2-0,4 \mathrm{mg} / \mathrm{kg}$ telesne mase jedanput nedeljno, dok kod odraslih pacijenata iznosi $0,2 \mathrm{mg} / \mathrm{kg}$ telesne mase/ jedanput nedeljno. MTX se ordinira u jednoj dozi, per os ili supkutano. Laboratorijske analize (KKS, kreatinin, hepatogram, pregled urina) rade se jednom nedeljno tokom prvog meseca, zatim na svake dve nedelje u drugom mesecu, a kasnije jednom mesečno ili na dva meseca. Savetuje se postupno snižavanje doze MTX po postizanju stabilnog značajnog poboljšanja kliničke slike ili remisije. Po postizanju remisije, savetuje se primena nižih doza MTX (5-10 mg) tokom nekoliko meseci. Kod odraslih pacijenata, neophodna je kontracepcija pre započinjanja terapije, tokom terapije i šest meseci po obustavljanju terapije. Folna kiselina, $5 \mathrm{mg}$, primenjuje u jednoj dozi, $48 \mathrm{~h}$ nakon ordiniranog MTX.

Azatioprin. Azatioprin se koristi u Velikoj Britaniji i SAD u lečenju adultnih formi AD. Savetuje se doza od $2,5 \mathrm{mg} / \mathrm{kg}$ telesne mase/dnevno, posle sedamnaeste godine života (58). Rutinski se pre uvođenja azatioprina kontrolišu KKS, biohemijski parametri krvi i pregled urina. Kontrola ovih parametara neophodna je i tokom terapije. Neophodna je kontracepcija tokom terapije azatioprinom.

Biološki lekovi. Veći broj bioloških lekova (ustekinumab, fezakinumab, apremilast, dupilumab, OC000459) primenjivan je u lečenju $\mathrm{AD}$, sa rezultatima koji obećavaju, međutim, za sada se nigde u svetu ovi preparati još uvek ne koriste u rutinskoj terapiji $\operatorname{AD}(59,60)$. Potreban je veći broj studija i duže praćenje pacijenata da bi se pouzdano procenili efikasnost i bezbednost primene ovih preparata $u$ lečenju $\mathrm{AD}$.

\section{Opšte mere}

\section{Održavanje higijene}

Kožu treba temeljno očistiti, ali nežno i pažljivo, kako bi se uklonile kruste u slučaju bakterijske superinfekcije. Kupanje treba da traje oko 5-10 minuta, pri temperaturi vode od 27 do $30^{\circ} \mathrm{C}$. Savetuje se nanošenje uljanih kupki poslednja 2 minuta kupanja, kako bi se izbegla dehidracija epiderma. Dodavanje natrijum-hipohlorita u kadu $s$ vodom može biti koristno, s obzirom na njegovo antibakterijsko dejstvo (8).

Kupanje u slanoj vodi može pogodovati pacijentima sa impetiginizovanim lezijama ili prisutnom ihtiozom. Pokazano je da je tvrdoća vode u vezi 
$s$ povećanom prevalencijom $\mathrm{AD}$, tj. da tvrda voda povećava rizik za razvoj atopijskog dermatitisa kod dece (61).

Emolijensi se prvenstveno nanose odmah posle kupanja ili tuširanja, dok je koža još uvek vlažna. Noviji radovi ukazuju da ograničavanje korišćenja sapuna i primena emolijenata najmanje jednom dnevno može smanjiti rizik od nastanka atopijskog dermatitisa (62).

\section{Odevanje}

Nošenje mekane pamučne odeće i izbegavanje iritirajućih tkanina u kontaktu s kožom (pre svega vune, ali i svile) od suštinskog je značaja za izbegavanje iritacije kože. Takođe, treba izbegavati okluzivnu odeću koja povećava toplotu kože, a tokom zimskih meseci treba izbegavati pretopljavanje dece. Niska vlažnost tokom zime i grejanje u stanovima povećava suvoću kože, tako da se može savetovati upotreba ovlaživača vazduha. Postoji konsenzus da osobe sa atopijskim dermatitisom treba da izbegavaju zanimanja kod kojih postoji mogućnost oštećenja kože ili postoji kontakt $s$ iritantnim supstancijama (8).

\section{Uslovi življenja}

Brojni faktori i supstancije iz okoline mogu da iritiraju osetljivu kožu pacijenata sa atopijskim dermatitisom i mogu da dovedu do nastanka ili pogoršanja ekcema. Oni mogu biti fizički, kao što su mehanički iritansi (npr. vuna), hemijski (kiseline, rastvarači, voda) ili biološki (mikroorganizmi). Informisanje pacijenata i članova njihovih porodica o značaju i ulozi nespecifičnih iritanasa za nastanak ekcema je veoma važan preduslov za uspešno lečenje pacijenata $s$ atopijskim dermatitisom.

Mnogi pacijenti su već svesni činjenice da kontakt sa životinjama može da dovede do pogoršanja simptoma na koži. Izloženost mačjoj dlaci tokom detinstva može povećati rizik od nastanka atopijskog dermatitisa, naročito kod dece koja imaju mutaciju gena za filagrin $(8,63)$. Nema dokaza da kontakt sa psima povećava rizik za nastanak atopijskog dermatitisa (8).

Pušenje cigareta treba izbegavati u prostorijama gde borave deca $s$ atopijskim dermatitisom, jer to može dovesti do povećanja iritacije i svraba i može da poveća sklonost ka kasnijem razvoju astme.
Mnogi pacijenti imaju problem s lučenjem i retencijom znoja tokom letnjih meseci, što dovodi do povećanja svraba. Ipak, decu s atopijskim dermatitisom treba ohrabriti da se aktivno bave sportom. Plivanje može biti odličan sport za decu sa atopijskim dermatitisom, ukoliko se dobro toleriše izlaganje hlorisanoj vodi. Pre plivanja se savetuje aplikacija emolijenata na celu površinu kože i odmah posle plivanja kupanje uljanom kupkom uz dodatnu aplikaciju emolijenata. Boravak u klimatizovanim prostorijama tokom letnjih meseci značajno može smanjiti osećaj svraba.

\section{Ishrana}

Među alergenima hrane, kravlje mleko, jaja, pšenica, soja, orasi i kikiriki su najčešće odgovorni za nastanak ili pogoršanje ekcema u ranom detinjstvu. Dvostruko slepo, placebo-kontrolisano izlaganje hrani smatra se zlatnim standardom za dijagnozu alergije na hranu (64). U sistematskom pregledu osam randomizovanih, kontrolisanih studija (57) koje su proučavale efekat eliminacione dijete kod pacijenata sa atopijskim dermatitisom pokazano je da ne postoje ubedljivi dokazi da je eliminaciona dijeta (npr. jaja i mleko) korisno za pacijente sa atopijskim dermatitisom. Međutim, u drugoj studiji pokazano je da je izostavljanje jaja u ishrani dovelo do poboljšanja atopijskog dermatitisa kod pacijenata koji su imali kliničke simptome posle prethodnog konzumiranja jaja (65).

$\mathrm{Ne}$ savetuje se da pacijenti sa atopijskim dermatitisom, kod kojih nije dokazana alergija na hranu, sprovode restrikcione dijete (66). Pacijenti s umerenim i teškim atopijskim dermatitisom treba da se pridržavaju eliminacione dijete one vrste hrane koja provocira ranu ili kasnu reakciju na koži koja je pokazana posle sprovedenog kontrolisanog oralnog provokacionog testa (8).

Postoje određeni podaci da probiotici mogu biti korisni i bezbedni u prevenciji atopijskog dermatitisa, sa smanjenjem rizika za oko 20\% (67). Međutim, i dalje postoji nejasnoća kada i kome treba dati probiotike (majkama pre rođenja deteta pod rizikom za razvoj $\mathrm{AD}$, deci posle rođenja, ili oboje) i koji specijes i soj bakterija treba dati. Za razliku od verovatno pozitivnog preventivnog dejstva, nije pokazana efikasnost probiotika kod pacijenata $s$ već razvijenim atopijskim dermatitisom (68). 


\section{Alternativni vidovi lečenja}

$\mathrm{Ne}$ postoje odgovarajući dokazi da fitoterapija, aromaterapija, akupunktura, homeopatija, kineska tradicionalna medicina ili biorezonanca imaju pozitivan efekat u lečenju atopijskog dermatitisa (8).

\section{Skraćenice}

$\mathrm{AD}$ - atopijski dermatitis

EASI - indeks procene težine i površine ekcema

(engl. Eczema area and severity index)

FTU - jedinica vrha prista (engl. finger-tip unit)

JAK - Janus kinaza

MTX - metotreksat

nbUVB - UVB zraci uskog spectra (engl.

Narrow-band UVB)

PDE4 - fosfodiesteraza 4

SCORAD - indeks procene težine atopijskog

dermatitisa (engl. Scoring atopic dermatitis)

Th - T-pomoćničke

TKS - topikalni kortikosteroidi

TKI - topikalni inhibitori kalcineurina

UVA - ultravioletni zraci spektra A

UVB - ultravioletni zraci spektra B

\section{Izjava}

Ovaj rad delimično je finansiran sredstvima Ministarstva nauke Republike Srbije sa projekata br. 175065, 175038, 41018 i 43012.

\section{Literatura}

1. Wollenberg A, Oranje A, Deleuran M, Simon D, Szalai Z, Kunz B, et al. ETFAD/EADV Eczema task force 2015 position paper on diagnosis and treatment of atopic dermatitis in adult and paediatric patients. J Eur Acad Dermatol Venereol. 2016;30(5):729-47.

2. Williams HC. Clinical practice. Atopic dermatitis. N Engl J Med. 2005;352(22):2314-24.

3. Bingefors K, Svensson $\AA$, Isacson D, Lindberg M. Self-reported lifetime prevalence of atopic dermatitis and co-morbidity with asthma and eczema in adulthood: a population-based crosssectional survey. Acta Derm Venereol. 2013;93(4):438-41.

4. Eichenfield LF, Tom WL, Chamlin SL, Feldman SR, Hanifin JM, Simpson EL, et al. Guidelines of care for the management of atopic dermatitis. Section 1. Diagnosis and assessment of atopic dermatitis. J Am Acad Dermatol. 2011;70(2):338-51.

5. Schneider L, Tilles S, Lio P, Boguniewicz M, Beck L, LeBovidge J, et al. Atopic dermatitis: a practice parameter update 2012. J Allergy Clin Immunol. 2013;131(2):295-9.

6. Leung DYM, Eichenfield LF, Boguniewicz M. Atopic Dermatitis (atopic eczema). In: Goldsmith A, Katz S, Gilchrist B, Paller A, Leffell D, Wolff K, editors. Fitzpatrick's dermatology in general medicine. 8th ed. New York: McGraw Hill Medical; 2012. p. 165-82.

7. Lipozenčić J, Ljubojević S, Gregurić S. Atopijski dermatitis u djece i odraslih [Atopic dermatitis in children and adults]. Acta Med Croatica. 2011;65(2):87-96.

8. Ring J, Alomar A, Bieber T, Deleuran M, Fink-Wagner A, Gelmetti C, et al. Guidelines for treatment of atopic eczema (atopic dermatitis) part I. J Eur Acad Dermatol Venereol. 2012;26(8):1045-60.

9. Galli E, Neri I, Ricci G, Baldo E, Barone M, Belloni Fortina A, et al. Consensus Conference on Clinical Management of Pediatric Atopic Dermatitis. Ital J Pediatr. 2016;42:1-25.

10. Wollenberg A, Wetzel S, Burgdorf WH, Haas J. Viral infections in atopic dermatitis: pathogenic aspects and clinical management. J Allergy Clin Immunol. 2003;112(4):667-74.

11.Wollenberg A, Zoch C, Wetzel S, Plewig G, Przybilla B. Predisposing factors and clinical features of eczema herpeticum: a retrospective analysis of 100 cases. J Am Acad Dermatol. 2003;49(2):198-205.

12.Darabi K, Hostetler SG, Bechtel MA, Zirwas M. The role of Malassezia in atopic dermatitis affecting the head and neck of adults. J Am Acad Dermatol. 2009;60(1):125-36.

13.McPherson T. Current understanding in pathogenesis of atopic dermatitis. Indian J Dermatol. 2016;61(6):649-55.

14.Peng W, Novak N. Pathogenesis of atopic dermatitis. Clin Exp Allergy. 2015;45(3):566-74.

15.Hanifin JM, Rajka G. Diagnostic features of atopic dermatitis. Acta Derm Venereol. 1980;92(Suppl):44-7.

16. Brenninkmeijer EE, Schram ME, Leeflang MM, Bos JD, Spuls PI. Diagnostic criteria for atopic dermatitis: a systematic review. Br J Dermatol. 2008;158(4):754-65.

17.Williams HC, Burney PG, Pembroke AC, Hay RJ. The U.K. working party's diagnostic criteria for atopic dermatitis. III. Independent hospital validation. $\mathrm{Br} \mathrm{J}$ Dermatol. 1994;131(3):406-16.

18.Eichenfield LF, Tom WL, Chamlin SL, Feldman SR, Hanifin JM, Simpson EL, et al. Guidelines of care for the management of atopic dermatitis: section 1. Diagnosis and assessment of atopic dermatitis. J Am Acad Dermatol. 2014;70(2):338-51.

19.Bos JD, Van Leent EJ, Sillevis Smitt JH. The millennium criteria for the diagnosis of atopic dermatitis. Exp Dermatol. 1998;7(4):132-8.

20.Diepgen TL, Sauerbrei W, Fartasch M. Development and validation of diagnostic scores for atopic dermatitis incorporating criteria of data quality and practical usefulness. J Clin Epidemiol. 1996;49(9):1031-8.

21.Bieber T, Akdis C, Lauener R, Traidl-Hoffmann C, SchmidGrendelmeier P, Schäppi G, et al. Global Allergy Forum and 3rd Davos Declaration 2015: Atopic dermatitis/eczema: challenges and opportunities toward precision medicine. Allergy. 2016;71(5):588-92.

22.Silverberg JI, Nelson DB, Yosipovitch G. Addressing treatment challenges in atopic dermatitis with novel topical therapies. J Dermatolog Treat. 2016;27(6):568-76.

23.Paller AS, Mancini AJ. Eczematous eruptions in childhood. In: Paller AS, Mancini AJ, editors. Hurwitz clinical pediatric dermatology. Philadelphia: Elsevier Saunders; 2006. p. 49-84.

24.Sathishkumar D, Moss C. Topical therapy in atopic dermatitis in children. Indian J Dermatol. 2016;61(6):656-61. 
25.Angelova-Fischer I, Neufang G, Jung K, Fischer TW, Zillikens D. A randomized, investigator-blinded efficacy assessment study of stand-alone emollient use in mild to moderately severe atopic dermatitis flares. J Eur Acad Dermatol Venereol. 2014;28 Suppl 3:9-15.

26.Mahe YF, Perez MJ, Tacheau C, Fanchon C, Martin R, Rousset F, et al. A new Vitreoscilla filiformis extract grown on spa waterenriched medium activates endogenous cutaneous antioxidant and antimicrobial defenses through a potential Toll-like receptor 2/protein kinase C, zeta transduction pathway. Clin Cosmet Investig Dermatol. 2013;6:191-6.

27. Bianchi P, Theunis J, Casas C, Villeneuve C, Patrizi A, Phulpin $\mathrm{C}$, et al. Effects of a new emollient-based treatment on skin microflora balance and barrier function in children with mild atopic dermatitis. Pediatr Dermatol. 2016;33(2):165-71.

28. Tollefson MM, Bruckner AL, Section on Dermatology. Atopic dermatitis: skin-directed management. Pediatrics. 2014;134(6):e1735-44.

29.Devillers AC, Oranje AP. Efficacy and safety of 'wet-wrap' dressings as an intervention treatment in children with severe and/or refractory atopic dermatitis: a critical review of the literature. Br J Dermatol. 2006;154(4):579-85.

30. Wollenberg A, Bieber T. Proactive therapy of atopic dermatitis - an emerging concept. Allergy. 2009;64(2):276-8.

31.Meurer M, Eichenfield LF, Ho V, Potter PC, Werfel T, Hultsch T. Addition of pimecrolimus cream $1 \%$ to a topical corticosteroid treatment regimen in paediatric patients with severe atopic dermatitis: a randomized, double-blind trial. J Dermatolog Treat. 2010;21(3):157-66.

32.Schmitt J, von Kobyletzki L, Svensson A, Apfelbacher C. Efficacy and tolerability of proactive treatment with topical corticosteroids and calcineurin inhibitors for atopic eczema: Systematic review and meta-analysis of randomized controlled trials. Br J Dermatol. 2011;164(2):415-28.

33. Wollenberg A, Sidhu MK, Odeyemi I, Dorsch B, KoehneVolland R, Schaff M, et al. Economic evaluation of maintenance treatment with tacrolimus $0.1 \%$ ointment in adults with moderate to severe atopic dermatitis. $\mathrm{Br} \mathrm{J}$ Dermatol. 2008;159(6):1322-30.

34.Ruzicka T, Bieber T, Schöpf E, Rubins A, Dobozy A, Bos JD, et al. A short-term trial of tacrolimus ointment for atopic dermatitis. N Engl J Med. 1997;337(12):816-21.

35. Chen SL, Yan J, Wang FS. Two topical calcineurin inhibitors for the treatment of atopic dermatitis in pediatric patients: a meta-analysis of randomized clinical trials. J Dermatolog Treat. 2010;21(3):144-56.

36. BornhövdEC, BurgdorfWHC, WollenbergA. Immunomodulatory macrolactams for topical treatment of inflammatory skin diseases. Curr Opin Investig Drugs. 2002;3(5):708-12.

37. Napadow V, Li A, Loggia ML, Kim J, Mawla I, Desbordes $\mathrm{G}$, et al. The imagined itch: brain circuitry supporting nocebo-induced itch in atopic dermatitis patients. Allergy. 2015;70(11):1485-92.

38. Eberlein B, Eicke C, Reinhardt HW, Ring J. Adjuvant treatment of atopic eczema: assessment of an emollient containing N-palmitoylethanolamine (ATOPA study). J Eur Acad Dermatol Venereol. 2008;22(1):73-82.

39. Reimann S, Luger T, Metze D. Topische Anwendung von Capsaicin in der Dermatologie zur Therapie von Juckreiz und
Schmerz. Hautarzt. 2000;51(3):164-72.

40.Drake LA, Fallon JD, Sober A. Relief of pruritus in patients with atopic dermatitis after treatment with topical doxepin cream. The Doxepin Study Group. J Am Acad Dermatol. 1994;31(4):613-6.

41.Stevens MT, Edwards AM. The effect of $4 \%$ sodium cromoglicate cutaneous emulsion compared to vehicle in atopic dermatitis in children - a meta-analysis of total SCORAD scores. J Dermatolog Treat. 2015;26(3):284-90.

42.Nakai K, Yoneda K, Murakami Y, Koura A, Maeda R, Tamai A, et al. Effects of topical $\mathrm{N}$-acetylcysteine on skin hydration/ transepidermal water loss in healthy volunteers and atopic dermatitis patients. Ann Dermatol. 2015;27(4):450-1.

43.Silverberg JI, Nelson DB, Yosipovitch G. Addressing treatment challenges in atopic dermatitis with novel topical therapies. J Dermatolog Treat. 2016;27(6):568-76.

44.Jarnagin K, Chanda S, Coronado D, Ciaravino V, Zane LT, Guttman-Yassky E, et al. Crisaborole topical ointment, 2\%: a nonsteroidal, topical, anti-inflammatory phosphodiesterase 4 inhibitor in clinical development for the treatment of atopic dermatitis. J Drugs Dermatol. 2016;15(4):390-6.

45.Zane LT, Chanda S, Jarnagin K, Nelson DB, Spelman L, Gold LS. Crisaborole and its potential role in treating atopic dermatitis: overview of early clinical studies. Immunotherapy. 2016;8(8):853-66.

46.Zane LT, Kircik L, Call R, Tschen E, Draelos ZD, Chanda $S$, et al. Crisaborole topical ointment, $2 \%$ in patients ages 2 to 17 years with atopic dermatitis: A Phase $1 \mathrm{~b}$, Open-Label, Maximal-Use Systemic Exposure Study. Pediatr Dermatol. 2016;33(4):380-7.

47.Draelos ZD, Stein Gold LF, Murrell DF, Hughes MH, Zane LT. Post hoc analyses of the effect of crisaborole topical ointment, $2 \%$ on atopic dermatitis: associated pruritus from phase 1 and 2 clinical studies. J Drugs Dermatol. 2016;15(2):172-6.

48. Bissonnette R, Papp KA, Poulin Y, Gooderham M, Raman M, Mallbris L, et al. Topical tofacitinib for atopic dermatitis: a phase 2a randomized trial. Br J Dermatol. 2016;175(5):902-11.

49.Jacob SE, Castanedo-Tardan MP. Pharmacotherapy for allergic contact dermatitis. Expert Opin Pharmacother. 2007;8(16):2757-74.

50.De Benedetto A, Agnihothri R, McGirt LY, Bankova LG, Beck LA. Atopic dermatitis: a disease caused by innate immune defects? J Invest Dermatol. 2009;129(1):14-30.

51.Niebuhr M, Werfel T. Innate immunity, allergy and atopic dermatitis. Curr Opin Allergy Clin Immunol. 2010;10(5):463-8.

52.Darabi K, Hostetler SG, Bechtel MA, Zirwas M. The role of Malassezia in atopic dermatitis affecting the head and neck of adults. J Am Acad Dermatol. 2009;60(1):125-36.

53.Mayser P, Kupfer J, Nemetz D, Schäfer U, Nilles M, Hort W, et al. Treatment of head and neck dermatitis with ciclopiroxolamine cream - results of a double-blind, placebocontrolled study. Skin Pharmacol Physiol. 2006;19(3):153-9.

54.Legat FJ, Wolf P. Cutaneous sensory nerves: mediators of phototherapeutic effects? Front Biosci (Landmark Ed). 2009;14:4921-31.

55.Gambichler T, Kreuter A, Tomi NS, Othlinghaus N, Altmeyer P, Skrygan M. Gene expression of cytokines in atopic eczema before and after ultraviolet A1 phototherapy. Br J Dermatol. 2008;158(5):1117-20. 
56.Hong SP, Kim MJ, Jung MY, Jeon H, Goo J, Ahn SK, et al. Biopositive effects of low-dose UVB on epidermis: coordinate upregulation of antimicrobial peptides and permeability barrier reinforcement. J Invest Dermatol. 2008;128(12):2880-7.

57.Hoare C, Li Wan Po A, Williams H. Systematic review of treatments for atopic eczema. Health Technol Assess. 2000;4(37):1-191.

58.Berth-Jones J, Takwale A, Tan E, Barclay G, Agarwal S, Ahmed I, et al. Azathioprine in severe adult atopic dermatitis: a doubleblind, placebo-controlled, crossover trial. $\mathrm{Br} \mathrm{J}$ Dermatol. 2002;147(2):324-30.

59.Nomura T, Kabashima K. Advances in atopic dermatitis in 2015. J Allergy Clin Immunol. 2016;138(6):1548-55.

60.Simpson EL, Bieber T, Guttman-Yassky E, Beck LA, Blauvelt A, Cork MJ, et al. Two phase 3 trials of dupilumab versus placebo in atopic dermatitis. N Engl J Med. 2016; 375(24):2335-48.

61.McNally NJ, Williams HC, Phillips DR, Smallman-Raynor M, Lewis S, Venn A, et al. Atopic eczema and domestic water hardness. Lancet. 1998;352(9127):527-31.

62.Horimukai K, Morita K, Narita M, Kondo M, Kitazawa H, Nozaki M, et al. Application of moisturizer to neonates prevents development of atopic dermatitis. J Allergy Clin
Immunol. 2014;134(4):824-30.

63.Epstein TG, Bernstein DI, Levin L, Khurana Hershey GK, Ryan PH, Reponen T, et al. Opposing effects of cat and dog ownership and allergic sensitization on eczema in an atopic birth cohort. J Pediatr. 2011;158(2):265-71.

64. Bindslev-Jensen C. Standardization of double-blind, placebocontrolled food challenges. Allergy. 2001;56 Suppl 67:75-7.

65.Bath-Hextall F, Delamere FM, Williams HC. Dietary exclusions for improving established atopic eczema in adults and children: systematic review. Allergy. 2009;64(2):258-64.

66.Saeki H, Nakahara T, Tanaka A, Kabashima K, Sugaya M, Murota $\mathrm{H}$, et al. Clinical Practice Guidelines for the Management of Atopic Dermatitis 2016. J Dermatol. 2016;43(10):1117-45.

67.Madhok V, Futamura M, Thomas KS, Barbarot S. What's new in atopic eczema? An analysis of systematic reviews published in 2012 and 2013. Part 2. Treatment and prevention. Clin Exp Dermatol. 2015;40(4):349-54.

68. Foolad N, Brezinski EA, Chase EP, Armstrong AW. Effect of nutrient supplementation on atopic dermatitis in children: a systematic review of probiotics, prebiotics, formula, and fatty acids. JAMA Dermatol. 2013;149(3):350-5. 